\title{
Migration and population expansion of Abies, Fagus, Picea, and Quercus since 15000 years in and across the Alps, based on pollen-percentage threshold values
}

\author{
W.O. van der Knaap ${ }^{a}, *$, Jacqueline F.N. van Leeuwen ${ }^{a}$, Walter Finsinger ${ }^{a}$, Erika Gobet ${ }^{\mathrm{a}}$, \\ Roberta Pini ${ }^{\mathrm{b}}$, Astrid Schweizer ${ }^{\mathrm{c}}$, Verushka Valsecchi ${ }^{\mathrm{a}}$, Brigitta Ammann ${ }^{\mathrm{a}}$ \\ ${ }^{a}$ Institute of Plant Sciences, University of Bern, Altenbergrain 21, CH-3013 Bern, Switzerland \\ ${ }^{\mathrm{b}}$ C.N.R. - I.P.D.A., c/o Dip. di Scienze Geologiche e Geotecnologie, Piazza della Scienza 4, I-20126 Milan, Italy \\ ${ }^{\mathrm{c} S e m i n a r}$ für Vor- und Frühgeschichte der Johann Wolfgang Goethe-Universität, Grüneburgplatz 1, D-60323 Frankfurt am Main, Germany
}

Received 1 September 2003; accepted 25 June 2004

\begin{abstract}
Aims: The aim of this study is to explore the migration (colonization of new areas) and subsequent population expansion (within an area) since $15 \mathrm{ka}$ cal BP of Abies, Fagus, Picea, and Quercus into and through the Alps solely on the basis of high-quality pollen data.

Methods: Chronologies of 101 pollen sequences are improved or created. Data from the area delimited by $45.5-48.1^{\circ} \mathrm{N}$ and $6-14^{\circ} \mathrm{E}$ are summarized in three ways: (1) in a selection of pollen-percentage threshold maps (thresholds $0.5 \%, 1 \%, 2 \%, 4 \%, 8 \%$, $16 \%$, and $32 \%$ of land pollen); (2) in graphic summaries of 250-year time slices and geographic segments (lengthwise and transverse in relation to the main axis of the Alps) as pollen-percentage curves, pollen-percentage difference curves, and pollen-percentage threshold ages cal BP graphed against both the length and the transverse Alpine axes; and (3) in tables showing statistical relationships of either pollen-percentage threshold ages cal BP or pollen expansion durations ( = time lapse between different pollenpercentage threshold ages cal BP) with latitude, longitude, and elevation; to establish these relationships we used both simple linear regression and multiple linear regression after stepwise-forward selection.

Results: The statistical results indicate that (a) the use of pollen-percentage thresholds between $0.5 \%$ and $8 \%$ yield mostly similar directions of tree migration, so the method is fairly robust, (b) Abies migrated northward, Fagus southward, Picea westward, and Quercus northward; more detail does not emerge due to an extreme scarcity of high-quality data especially along the southern foothills of the Alps and in the eastern Alps. This scarcity allows the reconstruction of one immigration route only of Abies into the southern Alps. The speed of population expansion (following arrival) of Abies increased and of Picea decreased during the Holocene, of Fagus it decreased especially during the later Holocene, and of Quercus it increased especially at the start of the Holocene.
\end{abstract}

(C) 2004 Elsevier Ltd. All rights reserved.

\section{Introduction}

\subsection{General introduction}

Published palynological reconstructions of post-glacial migration routes of forest trees in and around the

\footnotetext{
*Corresponding author. Tel. +41-31-631-3868; fax: +41-31-6314942.

E-mail address: knaap@ips.unibe.ch (W.O. van der Knaap).
}

European Alps (or parts of them) vary considerably in the degree of geographic detail shown. In studies covering most of Europe (such as Huntley and Birks (1983) for major European trees, Gliemeroth (1997) for Picea and Quercus, and Brewer et al. (2002) for Quercus) the Alps present little differentiation. On the other hand, relatively much geographic detail is shown by regional studies such as Burga and Perret (1998); repeated in Burga and Hussendörfer (2001) dealing with Picea and Abies in Switzerland and a sequence of studies in the 
southwestern French and Italian Alps for Abies (Clerc, 1988; Brugiapaglia, 1996; Nakagawa, 1998). The studies on a sub-continental scale are for mountain regions disappointingly coarse because the relief has not or insufficiently been taken into account and because of the limited number of pollen sites used, leading to the feeling that more may be possible for the Alps with the additional pollen sites that we have at our disposal. The detailed studies, on the other hand, make use not only of pollen data in a geographic context but also of presentday circumstantial evidence such as (1) growth requirements in relation to climate and soil as well as competitive characteristics of tree species, (2) distribution of sub-specific tree taxa (sub-species, races, growth forms), (3) present-day climatic and geologic conditions of mountain valleys potentially functioning as migration routes in the past, (4) mountain ridges potentially hindering tree migration, and (5) inferred palaeo-climate during periods of tree migration. The results are appealing because they are wonderfully detailed and intuitively plausible, but they have the major disadvantage that the method to construct them fails to explain the inferred tree migration routes in terms of past or present environment, because this would involve circular argument of the worst sort. The present study endeavours to find out how much detail can be extracted from the data without over-stretching them, and focuses both on migration and on population expansion, concentrating on four tree taxa (Abies, Fagus, Picea, and Quercus). We lay weight on the distinction between 'migration', indicating the occupation of new areas, and 'population expansion', indicating the increase of plant populations. (Population expansion has therefore no spatial component, but describes a phase in population dynamics.) Our effort is to let the pollen data speak for themselves, i.e., without entering into speculations not supported by the data. We put emphasis on data quality, accepting palynological evidence only from sites that have a radiocarbon-based time scale and have less than 500 years between sample midpoints. We deal with a relatively large body of high-quality data compared to earlier studies, including data stored in ALPADABA (Alpine Palynological Data-Base, housed in Bern, Switzerland; see van der Knaap and Ammann, 1997) and additional, partly unpublished data.

The Alps are of special interest in the reconstruction of post-glacial tree migration for two reasons. One reason is that some of the refuges of those trees are thought to be located at the southern edge of the area studied or very close by (see, e.g., Huntley and Birks, 1983; Bennett et al., 1991). A refuge is understood here as the region to which a tree population was reduced during the part of the last glaciation most unfavourable for that tree, just prior to its subsequent migration and expansion. Another reason of interest is that the Alps have undoubtedly interacted with tree migration, because of the relief modifying tree migration and population expansion compared to the situation in lowland Europe. The Alps are usually considered as a barrier, slowing down or changing the route of migration.

This study is part of the EU project FOSSILVA (Dynamics of forest tree biodiversity: linking genetic, palaeogenetic, and plant-historical approaches), which aims among other things to study tree migration and population expansion in western Europe. The Alps are studied separately because they pose their own specific problems of spatial and temporal scales.

A complicated process of tree migration and population expansion is to be expected in the Alps because of the strong relief resulting in heterogeneity in climate, geology, and soils, which control both phytogeographic regions and altitudinal vegetation belts. This leads to the existence or formation of migration barriers (altitudinal, climatic) locally interrupted by mountain passes, migration facilitation along valley bottoms and slopes, varying conditions of competition among trees, and the possibility of multiple immigration routes into the region studied.

We concentrate on the last 15 millennia (calibrated) for which a reasonable amount of high-quality data are available, excluding older periods. The part of the Alps and surroundings $45.5-48.1^{\circ} \mathrm{N}$ and $6-14^{\circ} \mathrm{E}$ has been studied in more detail with graphic and statistical methods.

\subsection{Separating tree immigration and population expansion in pollen diagrams}

It is beyond reasonable doubt that pollen percentages can be helpful to detect geographical patterns in tree migration on a European scale (References in Introduction). For individual sites, however, the first arrival of a tree near a site cannot be reliably determined on the basis of pollen alone. For that, macrofossils are needed (Birks and Birks, 2000). In most pollen sites, however, macrofossils were not studied. Presence of macrofossils generally indicates the presence of the tree near the site, but absence does not necessarily prove the absence of the tree, because macrofossils can be absent in sediment samples even if the tree species grows close (e.g., very few trees, low production of macrofossils, macrosample too small, ineffective transport of macrofossils from tree to sediment, or decomposition of macrofossils). Our results are based on pollen only, because the number of tree-macrofossil records in the study area is too small to reconstruct geographic patterns in population dynamics or to modify the reconstructions based on pollen. Geographical maps with ages at which pollen-percentage thresholds are crossed (Figs. 2-8) may give impressions of tree migration and population expansion, but they do not prove anything definitely for individual 
sites. Data on such maps are nevertheless valuable because they are based on high-quality pollen data produced and presented in a standardized way (as described below).

A tree can occur locally (as shown by macrofossils) even with very low pollen percentages $(<1 \%$, or even $<0.5 \%$; e.g., Picea in La Grande Basse, Vosges Mountains, France; Schweizer et al., 2004). A low threshold should therefore be chosen to reflect tree migration. There is a limit, however, to how low a pollen-percentage threshold can be usefully chosen. The timing BP of a very low pollen-percentage threshold $(0.5 \%)$ may cause problems in the interpretation, because (1) the role of chance is larger than with a higher threshold (low pollen percentages having a large counting error and a high sensitivity to the pollen sum), (2) low amounts of pollen may reflect long-distance transport and may therefore vary with extreme weather conditions (strong winds) rather than depend on the proximity of trees, (3) the influence of reworked pollen is larger, or (4) the influence of contamination (in the field and/or in the laboratory) is larger.

Lang (1992) refers to Birks (1986) following Watts (1973), who 'gave a rather convincing scheme for interpreting the phases of tree invasion and expansion from pollen-stratigraphic patterns, which is valid for anemophilous trees with medium to high pollen production', as follows: 'The pollen curve shows the absolute, empiric, and rational limit in correlation with absence of the taxon, its approach to the area limit, immigration, establishments, expansion, stabilization, and recession' (Table 1). The scheme might not apply for extremely high pollen producers like Pinus and possibly Quercus because of massive long-distance transport of pollen, or for extremely low pollen producers like Acer, Taxus, and Ilex, which are severely under-represented in the pollen assemblage and may go unnoticed when tree abundance is low to moderate. The absolute and empiric limits (but not the rational limit) are sensitive to the pollen sums used and to the total influx of other pollen types in the pollen sum. They are therefore of limited value when diagrams with widely differing pollen sums are used in regions different in overall vegetation composition (as is the case here). For the purpose of this paper it is important to distinguish between immigration or invasion (i.e., the first arrival of a tree at or near a locality, implying areal increase) and population expansion (i.e., population build-up in a region). The distinction is especially important if the population expansion is very slow (or if a time lapse occurs between immigration and population expansion).

Modelling is another approach to study the effects of tree immigration and population expansion in the pollen record. Davis and Sugita (1997, p. 191) modelled pollen dispersal using Sugita's (1994) POLLSCAPE simulation model. The output, validated through comparison with pollen records, suggests that small quantities of fossil pollen deposited just prior to the first marked increase in deposition may represent pollen blown in from an advancing population front rather than the local establishment of a small population, whereas actual invasion in the simulations was recorded by a steep increase in pollen loading ( $=$ influx, deposition) and pollen percentages. On the other hand, small isolated plant populations away from the main population front are hard to detect in the pollen record, and may therefore go unnoticed. This is a drawback in the use of pollen records for the reconstruction of tree migration.

Various pollen-percentage threshold values have been used to study tree migration. Gliemeroth (1997) studied the Holocene immigration of Picea and Quercus into Europe. In order to separate tree migration (arrival) from mass population expansion, she refrained from presenting isopollen maps on which the separation was considered not to be possible, but presented for each tree a migration map in steps of 1000 years (calibrated) based on a pollen-percentage threshold of $2 \%$ of total land pollen (considered to represent 'the first traces pointing to the very beginning of immigration') and a mass-expansion map in steps of 1000 years based on a pollen-percentage threshold of $7 \%$. To ensure a reliable chronology, she used pollen diagrams with at least five radiocarbon dates selected from a database of 1700 diagrams (Gliemeroth, 1995), supplemented by diagrams with less radiocarbon dates but with good pollenstratigraphic dating in order to fill geographic gaps.

Table 1

Phases of tree invasion and expansion from pollen-stratigraphic patterns ${ }^{\mathrm{a}}$

\begin{tabular}{lllll}
\hline & Pollen curve & Pollen behaviour & Phases of populations & Time \\
\hline 6 & (Decline) & Decline & Recession & $\uparrow$ \\
5 & Secondary peaks & Later maxima & & \\
5 & First peak & First maximum & Stability & $\uparrow$ \\
4 & Rational pollen limit & Rapid increase & Expansion (= building up of population) & $\uparrow$ \\
3 & Empiric pollen limit & Closed (continuous) curve & Immigration (= first arrival) and establishment & $\uparrow$ \\
2 & Absolute pollen limit & First scattered occurrences & Approaching area limit & $\uparrow$ \\
1 & No pollen & No occurrences & Absence & \\
& & & & \\
& & & & \\
\hline
\end{tabular}

\footnotetext{
${ }^{\mathrm{a}}$ Modified from Lang (1992).
} 
Comparison of the two types of map allowed her to estimate the time needed from immigration to mass expansion.

In pollen maps of Picea and Abies covering the Swiss and French Alps, Wegmüller (1977) used the first continuous pollen curve $(<5 \%$ of total land pollen but mostly $1-2 \%$ ) as an indication of immigration, and the threshold of $5 \%$ pollen to mark the beginning of population expansion.

Burga and Perret (1998) mapped and discussed the immigration patterns of Abies, Fagus, and Picea in Switzerland. For Abies they used $10 \%$ of total land pollen to mark the beginning of mass population expansion, and lower but undefined percentages to map migration. For Fagus they used 5\% pollen to mark 'the beginning of mass population expansion shortly after immigration'. For Picea they used mostly $2-5 \%$ pollen to map migration and $10 \%$ pollen to show population expansion. For Quercus they used 5\% pollen to mark mass population expansion, and, following Huntley and Birks (1983), 2\% pollen to mark local presence.

In this study, we use a range of tree pollen-percentage threshold values $(0.5 \%, 1 \%, 2 \%, 4 \%, 8 \%, 16 \%$, and $32 \%$ ) and discuss their significance in terms of tree immigration and population expansion.

\section{Description of study area and data}

\subsection{Alps}

The entire European Alps are of interest for the study of tree migration and population expansion. This paper discusses the part of the Alps that has a sufficient density of high-quality data. Suitable sites in the southwestern Alps are geographically very scarce compared to the central Alps, so this area is excluded. Very few data from the Alps east of $14^{\circ} \mathrm{E}$ are available. We include, however, a stretch of lower-lying land north of the Alps for which data are available. The part of the Alps and surroundings studied in more detail by graphic and statistical methods is delimited by $45.5^{\circ}$ and $48.1^{\circ} \mathrm{N}$ and by $6^{\circ}$ and $14^{\circ} \mathrm{E}$.

The Alps form a mountain chain stretching in an arc from SW to E over $1200 \mathrm{~km}$ long 140-240 km wide, and $0.2 \times 10^{6} \mathrm{~km}^{2}$ in surface area (Ozenda, 1988). The Alps are partly glaciated today (see maps Figs. 1A-B), and they were strongly glaciated during the Last Glacial Maximum. The Alps are shared by (from west to east) France, Italy, Switzerland, Germany, Liechtenstein, Austria, and Slovenia. The general macroclimate varies within the Alps with longitude, latitude, and position within the mountain system, coarsely generalized as follows: (sub-)oceanic climate in the west, and (sub)continental climate in the east; (sub-)mediterranean climate (mild in winter) in the south, temperate and cooler climate in the north. The position within the mountain system involves local mass effects (Mont Blanc massif, Matterhorn-Monte Rosa massif, Bernese Oberland) along with rain-sheltered inner-alpine parts with azonal continental traits (strongest in the interior valleys such as Briançonnais in France, Valais in Switzerland, upper Inn valley in Austria, and Vintschgau in South Tyrol in Italy). Meso-climate varies in a way usual in mountains mainly with altitude and exposure, showing gradients in temperature, precipitation, and radiation, resulting in gradients in duration of growing season and temperature sums.

Schmidli et al. (2002, p. 1051) describe the general pattern of precipitation in the Alps as follows: 'The main features of the spatial distribution are two high-precipitation bands extending along the northern and southern rim of the Alpine ridge, and drier conditions in the interior of the mountain range and over the adjacent flatland. The maximum along the southern rim is divided into two major wet zones, one centered over southern Switzerland-northern Italy and the other over eastern Italy-Slovenia. The monthly precipitation patterns exhibit pronounced seasonal and inter-annual variations (..).'.

\subsection{Sites}

The data used are derived from: ALPADABA (Alpine Palynological Data-Base, housed in Bern, Switzerland); EPD (European Pollen Database, housed in Arles, France); authors, including mostly insufficiently published or unpublished data; other data contributors (listed in Acknowledgements). Where necessary written permission to use the data has been obtained.

Study sites include lakes and mires. Fig. 1A shows the study sites and their numbers. Fig. 1B shows the study sites and their elevation in 100-m classes.

This paper concentrates mainly on the Holocene but reaches back into the Late Glacial (15 cal ka BP) as far as high-quality data are available. Suitable data of Late Glacial age are in fact far scarcer than Holocene data. A large proportion of published (and unpublished) Late Glacial data is less suitable for our purpose for various reasons: insufficient or missing radiocarbon control (often due to calcareous character of the sediment, scarcity of organic matter, or low sedimentation rates), presence of reworked pollen (falsifying results), very low pollen sums counted (often due to low pollen concentrations), or low temporal resolution.

\section{Methods}

\subsection{Dating and time scales}

The data used consist of 107 pollen diagrams from 101 sites, in which 8930 pollen spectra were analysed. 
Site Nos.



Fig. 1. (A-B) Maps of area with sites studied. Sites are shown as light brown dots. Glaciers are outlined in blue. Rivers and shores are drawn in red. Country boundaries are drawn as thick black lines. Approximate northern and southern foot of the Alps are sketched with thin black lines. Coordinates are degrees Greenwich. Labels of sites are placed on sites or close to it. (A) Site numbers. Original publications of pollen diagrams and of chronologies (site no. in brackets): Unpublished, by co-authors of this paper (45; 54; 95); Ammann, 1989 (15); Avigliano et al., 2000 (101); Beaulieu, 1977 (4; 91; 92; 96; 97; 98); Beaulieu and Goeury, 1987 (89); Beckmann, in press (45); Bortenschlager, 1970 (66); Bortenschlager, 1976 (84); Bortenschlager, 1984a (65; 66; 68; 72; 80; 82); Bortenschlager, 1984b (72); Brugiapaglia, 1996 manuscript (24; 29; 31); de Valk, 1981 (9; 10); Fäh, 1986 (53); Gaillard, 1984, 1985 (3); Gehrig, 1997 (60; 63); Gobet et al., 2000 (50); Gobet et al., 2003 (54); Hadorn, 1994 (5); Heeb and Welten, 1972 (25; 27 ; 30); Heuberger, 1977 (77; 79); Hüttemann and Bortenschlager, 1987 (79); Juvigné and Gewelt, 1987 (89); Küttel, 1977 (48); Küttel, 1979 (39; 40 ); Küttel, 1989 (47); Krisai et al., 1991 (86; 88; 87); Lotter, 1988 (44); Lotter, 1985 (23); Lotter and Boucherle, 1984 (23); Lotter and Fischer, 1991 (22); Lotter et al., 1992 (44); Lotter et al., 1996(?) (26); Markgraf, 1969 (34); Mitchell et al., 2001 (2); Nicol-Pichard, 1987 (90); Nicol-Pichard and Dubar, 1998 (94); Oeggl, 1988 (83); Pini, 2002 (55); Ravazzi, 2002 (101); Reille, 1991 (1; 11; 13); Richoz, 1997 (7); Rösch, 1983 , 1985 (49); Schneebeli, et al., 1989 (53); Schweizer et al., in preparation (8); Seiwald, 1980 (73; 74; 75; 76; 78); Tinner, 1998 (50; 51); Tinner and Conedera, 1995 (51); Tinner et al., 1999 (50; 51); Valsecchi, 1999 manuscript (101); van der Knaap and Ammann, 1997 (revised chronologies of: 14; 15; 16; 17; 19; 21; 22; 25; 27; 32; 33; 34; 36; 37; 38; 39; 40; 41; 42; 43; 46; 57; 59; 62); van der Knaap et al., 2000 (12; 13); van der Knaap and van Leeuwen, 2001 (45); van der Knaap et al., in press (26); Vorren et al., 1993 (67); Wahlmüller, 1985 (64; 69; 81); Wahlmüller, 1988, 1992 (85); Wahlmüller, 1990 (71); Watson, 1996 (99; 100 ); Wegmüller and Welten, 1973 (17); Wegmüller and Lotter, 1990 (22); Weirich and Bortenschlager, 1980 (70; 79$)$; Welten, 1977 (16); Welten, 1982a (6; $14 ; 16 ; 17 ; 18 ; 19 ; 20 ; 21 ; 22 ; 26 ; 27 ; 32 ; 33 ; 36 ; 37 ; 38 ; 39 ; 40 ; 41 ; 42 ; 43 ; 46)$; Welten, 1982b (56; 57; 58; 59; 61; 62); Wick, in preparation (52); Zbinden et al., 1989 (15; 44).(B) Elevations of sites in 100-m classes (midpoints; \pm 0.5$)$. (C) Transverse and lengthwise geographic segments to which sites are assigned; for explanation see text. Drawn grid lines delimit geographic segments. First digit of site labels is transverse geographic segment (approximately $\mathrm{W}-\mathrm{E}$ ); second digit is lengthwise segment (approximately $\mathrm{S}-\mathrm{N}$ ); sites outside geographical segments are labelled 0 . Labels may refer to several sites lying close together. 
Site elevations (100-m classes)

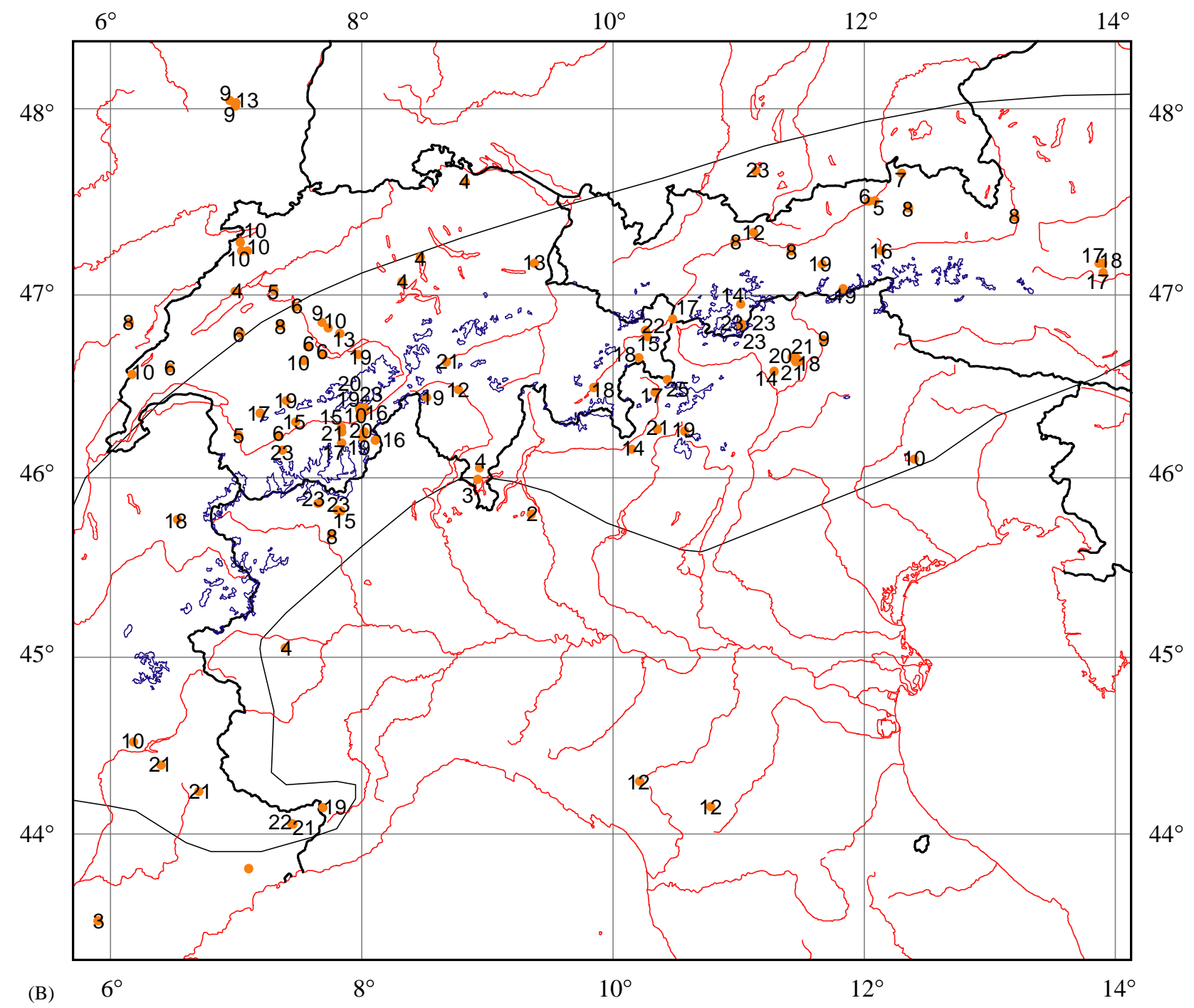

Fig. 1. (Continued)

The chronologies are based on 883 physical dates (radiocarbon dates and Laacher See tephra) supplemented by 427 dates based on pollen stratigraphy and chrono-correlation of sites lying close together. The first author of the present paper is responsible for most chronologies, partly published elsewhere (Van der Knaap and Ammann, 1997; Van der Knaap et al., 2000). Other chronologies were made by Lotter and Birks (2003) (site 35), Walter Finsinger (manuscript in prep.) (site 95), Gobet et al. (2003) (site 54), Lotter in Van der Knaap et al. (2004) (site 26), Tinner (1998) (sites 50, 51), and 7 Lucia Wick (2004) (site 52).

A calibrated time scale (years or ka BP; before AD $1950)$ is used. Radiocarbon years are calibrated with CALIB, versions 3.X and 4.X using the INTCAL98 calibration data set (Stuiver et al., 1998a,b). Calibrated radiocarbon dates and calibrated inferred pollen ${ }^{14} \mathrm{C}$ ages lay at the basis of the calibrated time scales. The reason to calibrate is that this results in the closest approximation to accurate calendar-year time scale, and that depth-age models are only meaningful and useful when based on calibrated dates (Telford et al., 2004).

The depth-age modelling of individual pollen diagrams is based on calibrated radiocarbon dates, coring date (providing an age for the top of the core), and inferred biostratigraphic dates. The latter have been used with caution, because there is a risk of circular reasoning. Biostratigraphic dates based on inferred treemigration ages are therefore not used. We used only pollen trends that depend with reasonable certainty directly on climatic forcing of a known age, including the transitions Oldest Dryas to Bølling, Allerød to Younger Dryas, and Younger Dryas to Preboreal (Holocene). The most commonly used inferred date is 
Transverse and lengthwise geographic segments

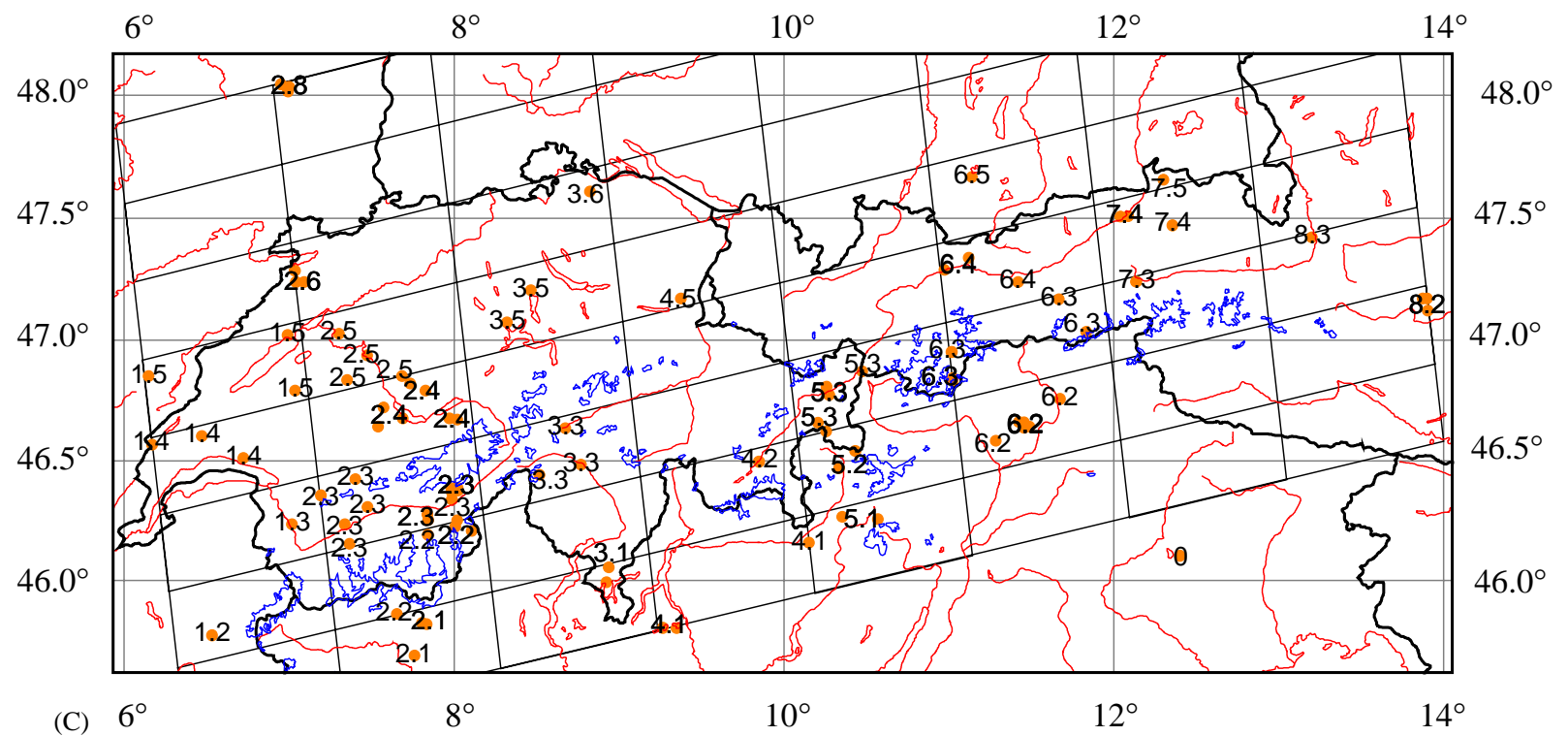

Fig. 1. (Continued)

the Younger Dryas/Preboreal transition. Accurate radiocarbon dating of this transition is problematic because sediment accumulation is mostly slow, and if this does not pose a problem the ${ }^{14} \mathrm{C}$ plateau in the period of interest requires wiggle-match dating (e.g., Gulliksen et al., 1998). We based the biostratigraphic dating of the Younger Dryas/Preboreal transition on the decline of pollen associated with steppe plants (mostly Artemisia and Chenopodiaceae). Another case where we accept inferred biostratigraphic dates is when several pollen diagrams of the same site are available and some have radiocarbon dates. Biostratigraphic chrono-correlation among such diagrams can be accepted, so that radiocarbon dates in different diagrams may complement each other. This is the case for Rotsee, Lac de Seedorfsee, and Nussbaumer Seen (sites $44,7,49)$.

\subsection{Temporal resolution and data selection}

Only parts of pollen diagrams with sufficient temporal resolution are used. Temporal resolution of a pollen sample is considered sufficient if the average distance of the sample midpoint to the two neighbouring sample midpoints is less than 500 years; on average it is $116 \pm 99$ years ( $1 \sigma$ standard deviation).

Six study sites have more than one pollen diagram. The diagrams vary within the site in dating control and/ or temporal resolution. Results from diagrams or parts of diagrams with less dating control and/or lower temporal resolution are not used.

\subsection{Selection of reliable pollen data}

Excluded are samples that are 'suspect' because of high tree-pollen percentages followed by a period of zero percentages. This phenomenon may reflect natural fluctuations in tree-population sizes, but the chances are larger that it is caused by either reworking of pollen from older sediments eroded in the catchment, or contamination of the pollen samples during handling in the field or laboratory. For practical reasons we excluded therefore any of the following cases: (1) High tree pollen percentages in the early Late Glacial soon disappearing a few spectra higher, which may well be caused by reworking. (2) Elevated tree pollen percentages in the Younger Dryas followed by low values, which even if not reworked are very unlikely indicative of tree-population expansion. They may, e.g., be caused by low local (or regional) pollen production, because of which regional (or extra-regional) tree pollen reaches elevated percentages. (3) Tree pollen maxima of short duration (one or a few spectra) prior to the first increase of the pollen type. Such maxima are suspect especially for several tree taxa together, and suggest sample contamination during handling. In order to reduce the subjectivity in exclusion of pollen samples, we applied these rules with rigour, avoiding exclusion of data that simply do not fulfil expectations but are otherwise not unusual biostratigraphically. Wegmüller (1977) used similar criteria to exclude 'doubtful' samples in his construction of migration and population-expansion maps for Picea and Abies. 


\subsection{Calculation and smoothing of pollen percentages}

Pollen percentages are calculated on a pollen sum ( $100 \%$ by definition) including all pollen and spores of vascular plants growing usually on dry soils. Excluded from the pollen sum are pollen and spores of obligate aquatic plants and also of notorious mire plants with a high production of pollen or spores (e.g., Cyperaceae, Monolete fern spores, Thelypteris palustris). Such a pollen sum is similar to that in a majority of published pollen diagrams, although spores are often excluded in their total. Our reason to include spores that with high probability can be connected with dry-soil Pteridophyta is that there is no ecological reason to treat Pteridophyta differently from other herbs, whereas purely taxonomic considerations are irrelevant; Pteridophyta are in our climate actually herbs in their growth form.

In order to smooth out random fluctuations in pollen percentages (including statistical counting errors and weather-determined pollen-production or -transport fluctuations), data were smoothed prior to determination of pollen-percentage threshold ages cal BP and expansion duration (defined below). For smoothing we used a data window moving through time. The data window contains up to five consecutive samples, but is limited to a maximum time interval of 500 years between the midpoints of the lower and upper sample in the data window. Pollen percentages and sample ages are averaged for each position of the data window. Smaller, nested data windows including the basal accepted level of the pollen diagrams were added in order to extract maximum information from the basal 5 pollen samples.

\subsection{Determination of pollen-percentage threshold ages cal BP and expansion duration}

Pollen-percentage threshold age cal BP is defined as the calibrated age of the first (smoothed) pollen sample in which the tree studied (Abies, Fagus, Picea, or Quercus) reaches a defined pollen-percentage threshold. Thresholds applied are $0.5 \%, 1 \%, 2 \%, 4 \%, 8 \%, 16 \%$, and $32 \%$. A threshold age is not used if this concerns the basal pollen sample of a pollen sequence used (after exclusion of 'suspect' pollen samples), because the pollen sequence may start after the actual immigration or population expansion of the tree studied. The threshold age is set to -1 if the threshold is never reached in a pollen sequence covering at least the period 1900-1000 cal BP. This period was selected as the youngest millennium that excludes the many pollen diagrams younger than 1000 BP (see van der Knaap et al., 2000), in which the threshold is not reached due to anthropogenic deforestation prior to $1000 \mathrm{BP}$.

Pollen-percentage expansion duration is defined as the time elapsing between one threshold age cal BP and the next, including $0.5-1 \%, 1-2 \%, 2-4 \%, 4-8 \%, 8-16 \%$, and $16-32 \%$. It is a measure of the speed of population expansion. The expansion duration is set to -1 if the upper threshold is never reached in a pollen sequence covering at least the period 1900-1000 cal BP.

Results that are very similar between pollen diagrams of the same site or of sites lying close together are combined (by averaging the ages). Results for two pollen diagrams are considered very similar if they concern the same tree taxon and threshold and are less than 400 year different; results for three pollen diagrams are very similar if the difference between minimum and maximum is less than 600 year.

\subsection{Maps and graphic geographic summaries of pollen- percentage data and threshold ages cal $B P$}

PanMap (1998) is used for drawing the geographical maps (Figs. 1ff).

Although the results of pollen-percentage threshold ages cal BP and expansion duration are shown here on maps in a geographic context (Figs. 2-8), geographic trends are in most cases only weakly visible. Geographic trends are therefore summarized in a number of different ways, each exposing different underlying features in the data.

In order to summarize the data and results graphically, spatial segments are designed (Fig. 1C). To optimize these geographic segments according to the orientation of the Alps, both the length axis through the Alps and the transverse axis perpendicular to it have been slightly tilted compared to Lat/Long directions to an approximately WSW-ENE length axis and an approximately SSE-NNW transverse axis. The length axis is devised to traverse both the western and the eastern inner-Alpine regions and thus to separate the southern from the northern Alps more effectively than a strict W-E axis does. (Schmidli et al., 2002 used a similar division between southern and northern Alps for the study of regional precipitation.) This makes a difference especially in the study of trends in southnorth direction. The length axis runs through $46^{\circ} \mathrm{N}, 6^{\circ} \mathrm{E}$ and $47^{\circ} \mathrm{N}, 12^{\circ} \mathrm{E}$. Both the length and the transverse axes runs through $46^{\circ} \mathrm{N}, 6^{\circ} \mathrm{E}$; this point is the arbitrary zero point for graphic and calculation purposes. Coordinates of sites on the length axis are calculated as $\left({ }^{\circ} \mathrm{E}-6\right)+\left({ }^{\circ} \mathrm{N}-46\right) / 6$ (in which ${ }^{\circ} \mathrm{E}$ and ${ }^{\circ} \mathrm{N}$ are degrees Greenwich Latitude and Longitude), on the transverse axis as $\left({ }^{\circ} \mathrm{N}-46\right)-\left({ }^{\circ} \mathrm{E}-6\right) / 6$. On the basis of these axes, the pollen sites in the area delimited by $45.5-48.1^{\circ} \mathrm{N}$ and $6-14^{\circ} \mathrm{E}$ are classified in eight transverse geographic segments of identical width on the length axis and similarly in eight lengthwise geographic segments on the transverse axis (Figs. 9-16).

Summarizing of pollen data is done in the following three ways (left, central, and right parts of Figs. 9-16): 
Abies: $\geq 0.5 \%$ pollen; centuries BP cal. (500-yr moving window)

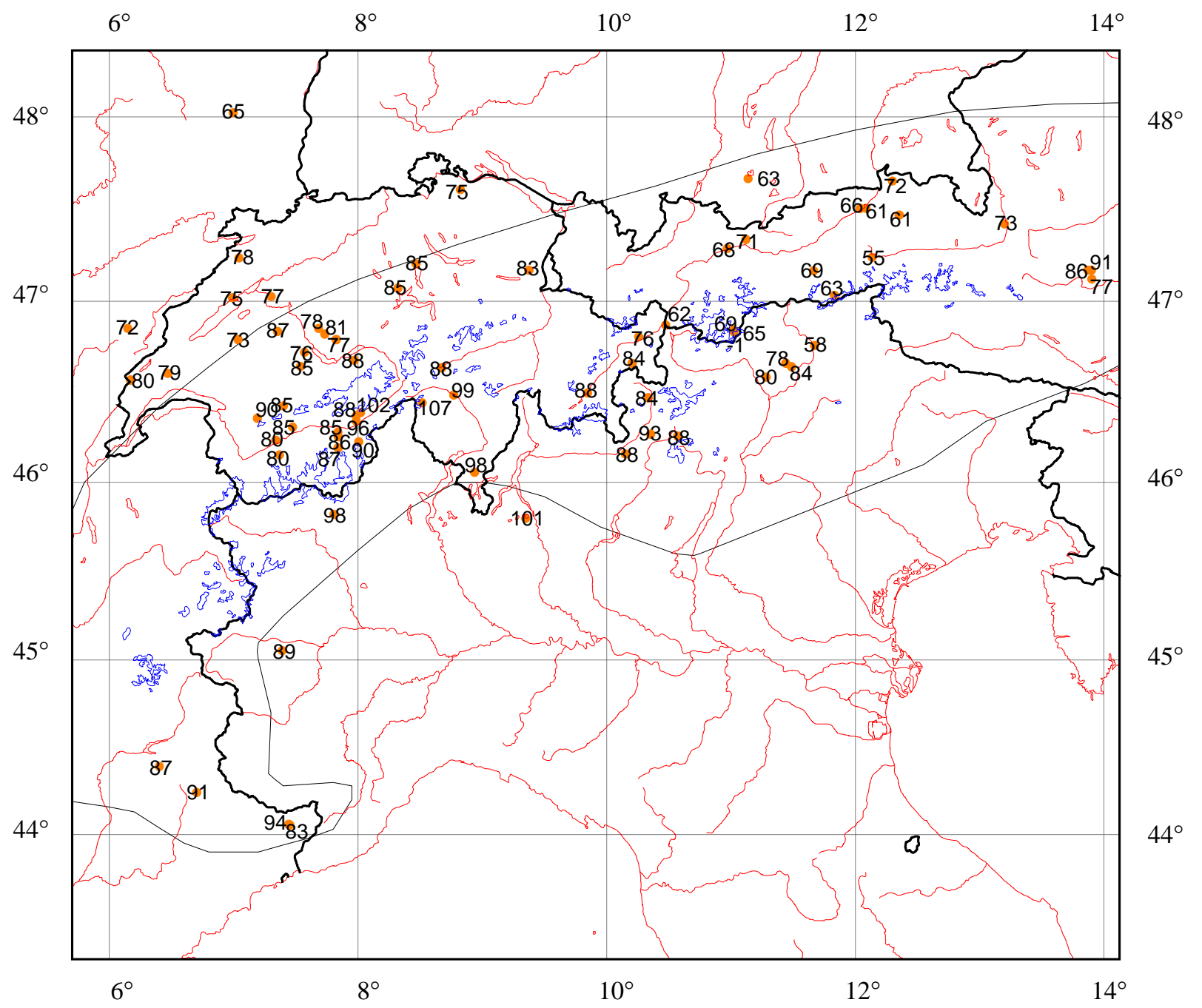

Fig. 2. Abies; threshold 0.5\%. Maps showing the ages cal BP that pollen-percentage thresholds are reached in 100-yr classes (cal BP), calculated in moving time windows (see text for details) for various thresholds $(0.5 \%, 1 \%, 2 \%, 4 \%, 8 \%, 16 \%$, and $32 \%)$; the selected maps shown have threshold ages with statistically significant relationships with longitude and/or latitude (see Table 2).

(1) Left parts of Figs. 9-16 show average pollen percentages per 250 year in geographic segments. Pollen percentages are summarized for each of the four trees by averaging pollen percentages per tree per 250-yr time slice per site, followed by averaging the results per tree per time slice per geographic segment.

(2) Middle parts of Figs. 9-16 show average pollenpercentage change per 250 year in geographic segments. Increases or decreases of tree-pollen percentages are summarized for each of the four trees by averaging pollen percentages per tree per 250 -yr time slice per site, calculating the increase or decrease in pollen percentages per tree per time slice per site, which is done by subtracting the averaged pollen percentage in the underlying time slice from that in the time slice, and averaging the results per tree per time slice per geographic segment.

Note that the average pollen-percentage change values (middle parts of Figs. 9-16) are not directly derived from the average pollen percentage values (left parts of Figs. 9-16). This results in some apparent discrepancies, because results of all time slices contribute to the average pollen percentages, whereas only the upper of each pair of adjacent time slices within sites contribute to the average pollen-percentage change.

(3) Right parts of Figs. 9-16 show LOWESS-smoothed pollen-percentage threshold ages cal BP. SYSTAT 5.02 (1993) is used for implementation. Pollen-percentage threshold ages cal BP are related graphically to site position on either the transverse or the lengthwise axis, and graphically smoothed by LOWESS (span 0.4). 
Fagus: $\geq 1 \%$ pollen; centuries BP cal. (500-yr moving window)

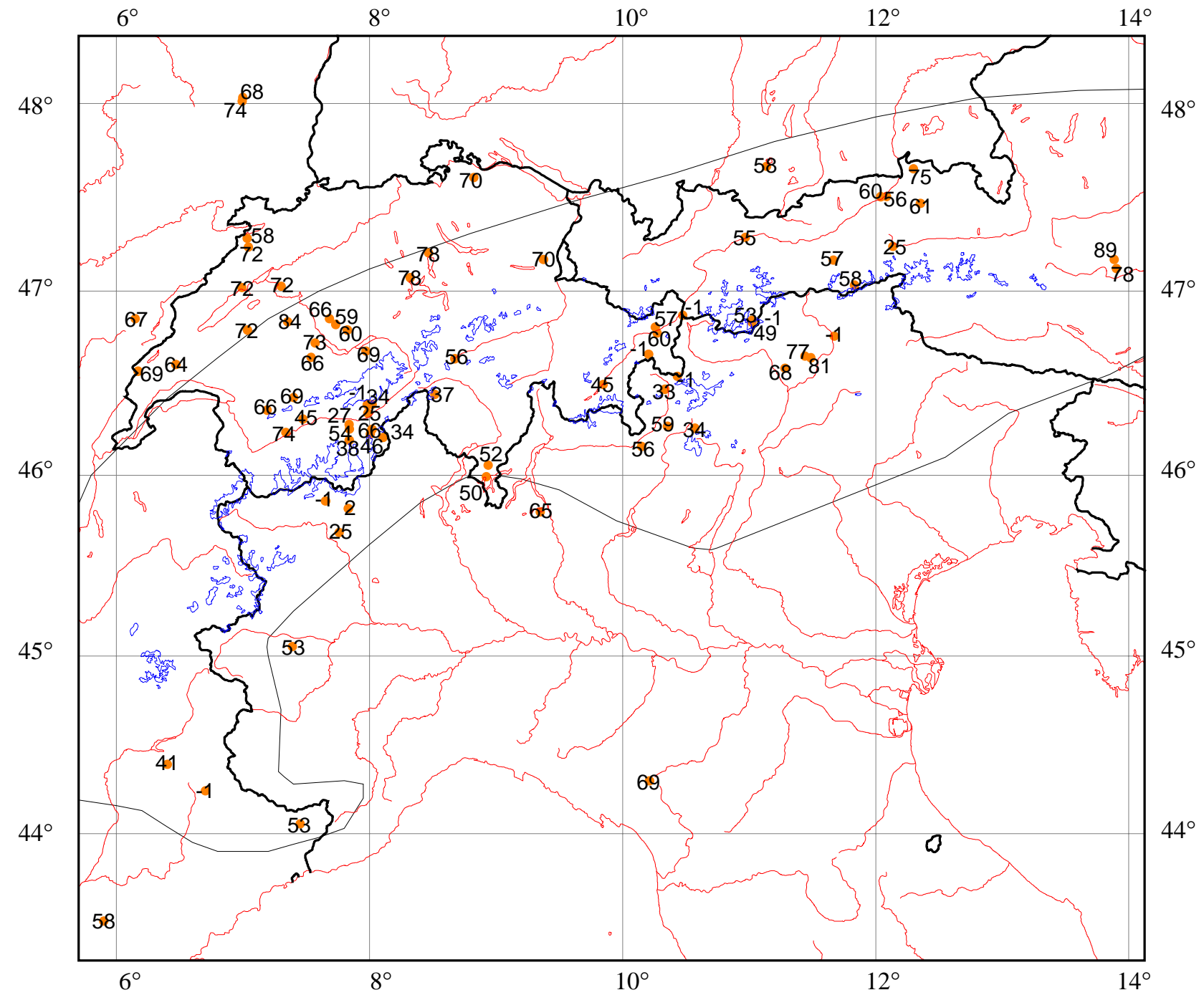

Fig. 3. Fagus; threshold 1\%. See caption to Fig. 2 for explanation.

\subsection{Statistical testing of geographical and temporal patterns}

Pollen-percentage threshold ages cal BP and pollenpercentage expansion duration (concepts explained in Section 3.5) may show geographic patterns (in relation to latitude, longitude, and elevation) because of tree migration and population expansion. In order to assess this statistically, linear regressions are carried out for the Alps north of $45.5^{\circ} \mathrm{N}$, east of $6^{\circ} \mathrm{E}$, between either pollenpercentage threshold age $\mathrm{BP}$ or pollen-percentage expansion duration as dependent variable and latitude, longitude, and elevation as independent variables. Regressions include simple linear regression between dependent and each independent variable, and multiple linear regression between dependent variable and stepwise forward selected independent variables. SYSTAT
5.02 (1993) is used for implementation. Results are shown in Tables 2 and 3. Temporal patterns in pollenpercentage expansion duration are statistically explored by simple linear regression in Table 4.

\section{Results}

\subsection{Tree migration and population expansion in relation to space (Tables 2 and 3, Figs. 9-16)}

Geographic aspects of tree migration and population expansion (in three dimensions: latitude, longitude, elevation) are explored statistically in two ways. Table 2 shows how the timing of tree migration and population expansion is related to space. Table 3 shows how the 
speed of tree-population expansion is related to space (Fig. 17).

The results in Tables 2 and 3 should be interpreted with caution because of a possible bias in the data, as some regions of the Alps important for tree dynamics are insufficiently covered, and there may exist geographical trends in the types of sites, which may vary with the pollen-percentage thresholds.

Statistical significance $(P<0.05)$ of simple linear regression amounts to ca. $39.5 \%$ of cases tested in Table 2 and to ca. $26 \%$ in Table 3, which lies markedly above the chance expectation of $5 \%$. The proportion of explained variance (adjusted multiple $R^{2}$ ) in multiple linear regression after stepwise forward selection is generally high in Table 2, low in Table 3.
Table 2 shows statistical linear relationships between pollen-percentage threshold ages cal BP of the trees studied and latitude, longitude, and elevation. The proportion of explained variance is extremely high for Picea (67-76\%) and high for Abies (mostly 27-49\%), Quercus (mostly 30-42\%), and Fagus (mostly 20-50\%). Statistical significance is strong, in decreasing order, in the relationships of Picea to longitude, Abies to latitude, Quercus to elevation, and Fagus to latitude.

\subsection{Population expansion in relation to age (Table 4,}

Fig. 17)

Average doubling times of pollen percentages as shown graphically in Fig. 17 are a proxy of doubling

Picea: $\geq 0.5 \%$ pollen; centuries BP cal. (500-yr moving window)

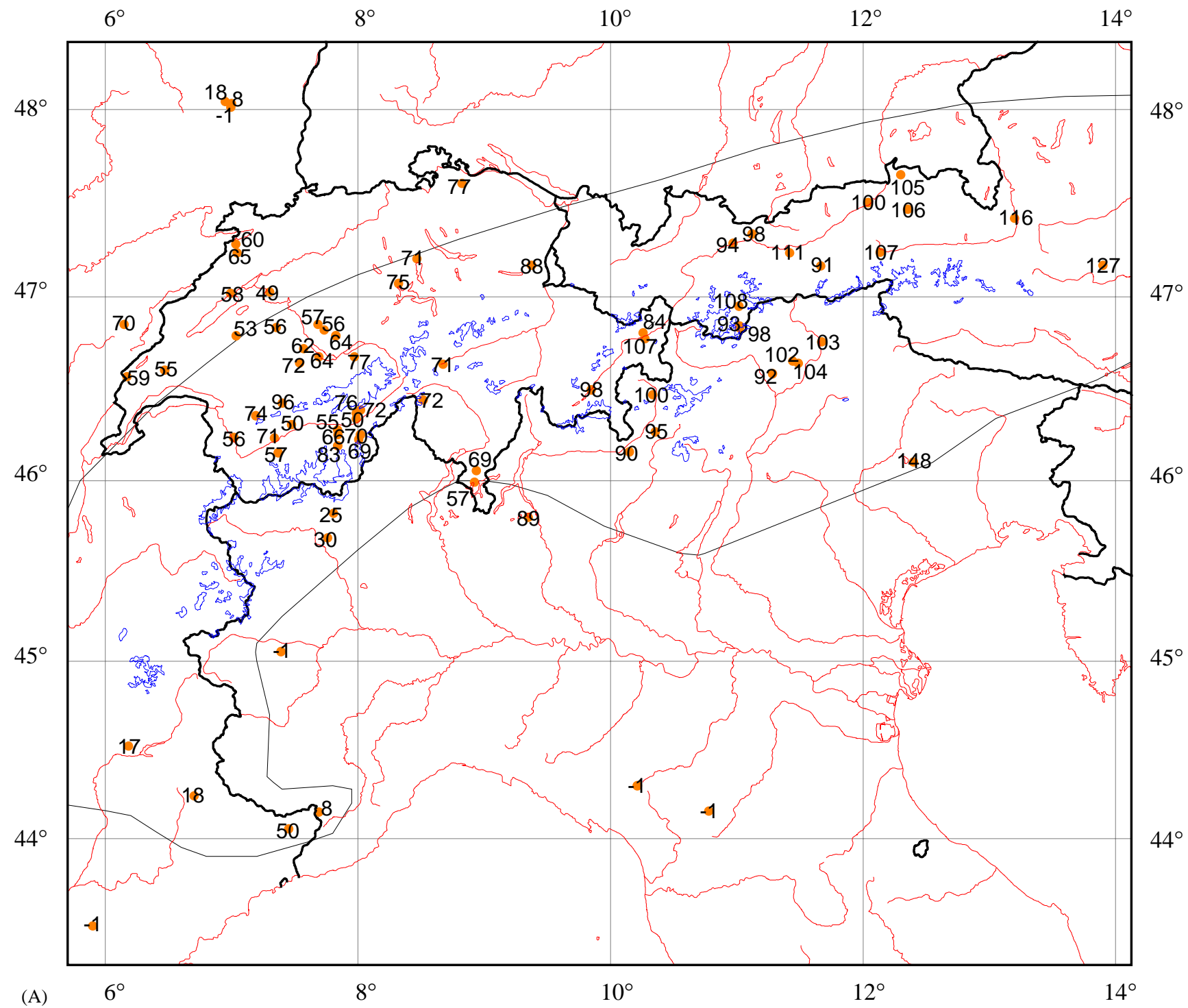

Fig. 4. (A) Picea; threshold 0.5\%, (B) Picea; threshold 4\%, (C) Picea; threshold 32\%. See caption to Fig. 2 for explanation. 
Picea: $\geq 4 \%$ pollen; centuries BP cal. (500-yr moving window)

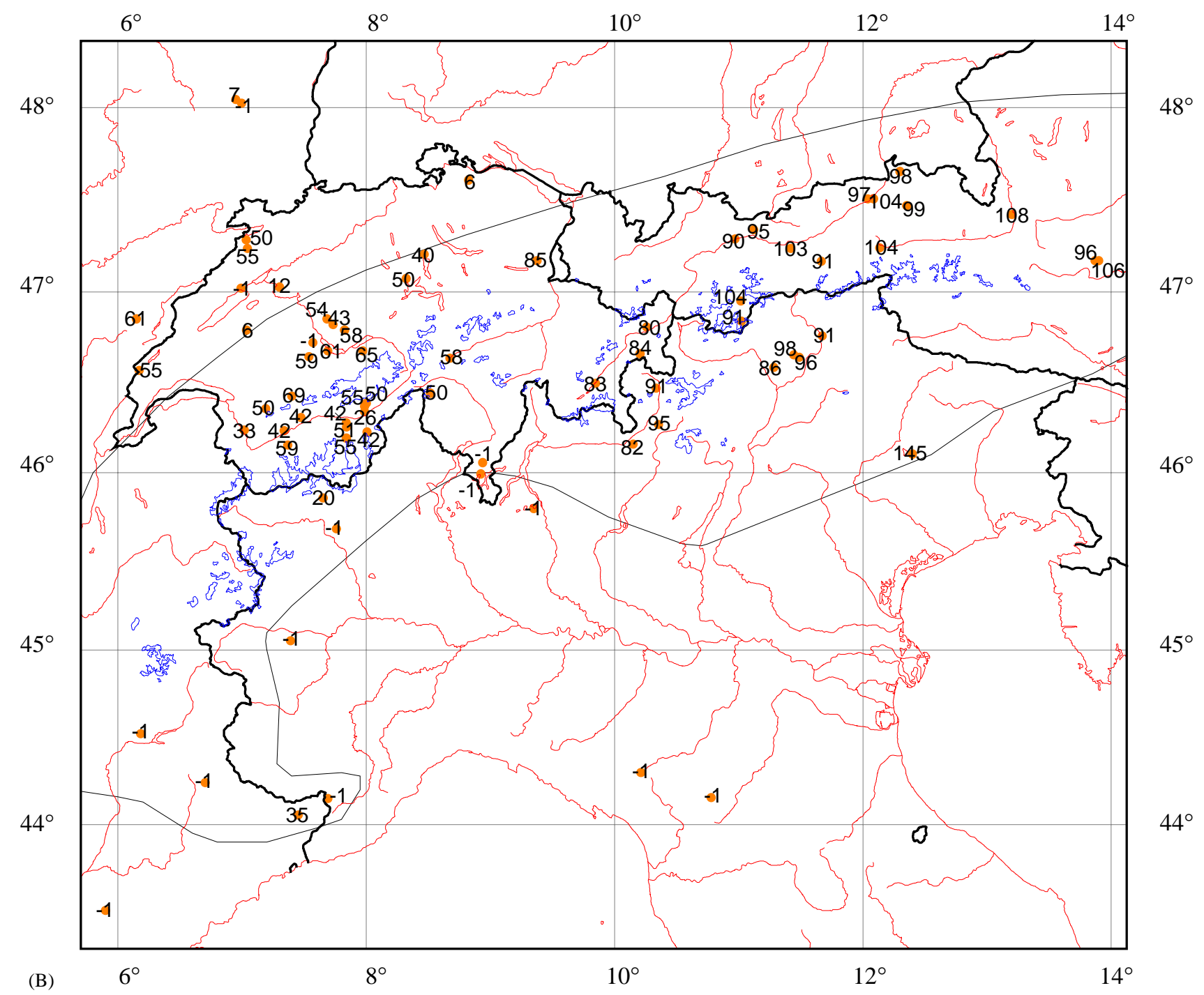

Fig. 4. (Continued)

times of tree populations. Average population doubling times range from $0.45 \mathrm{ka}$ in Abies to $1.22 \mathrm{ka}$ in Quercus, but the error bars larger than the actual values prevent further interpretation (see figure caption). Any trends in Fig. 17 should be interpreted with caution not only because of the large error bars but also because the selection of sites is different for each data point. Therefore, the slightly increasing trends in Abies, Fagus, and Picea may be spurious. The longer durations of population doubling of Quercus above $8 \%$ pollen coincide with a small number of records (see Table 3 ).

The speed of population expansion in relation to the age cal BP for the expansion is explored in Table 4. This table lists results of simple linear regression between pollen-percentage threshold ages cal BP and the time elapsing from this (lower) threshold to a later (upper) threshold. Positive correlation implies that the speed of tree-population expansion was faster when the expan- sion started later, negative correlation that it was slower. Similar to Tables 2 and 3 and for the same reasons, the results in Table 4 should be interpreted with caution; ca. $25 \%$ of cases tested are statistically significant $(P<0.05)$ and ca. $37 \%$ of cases tested have $P$-value $<0.10$, both of which lie markedly above chance expectations (which are $5 \%$ for statistical significance, or about 1 case per tree taxon).

\section{Interpretation}

\subsection{Tree migration and population expansion in relation to space (Tables 2 and 3, Figs. 9-16)}

In the spatial relationships (latitude, longitude, and elevation) of tree migration (Table 2) and population expansion (Table 3), the results in terms of positive or 
Picea: $\geq 32 \%$ pollen; centuries BP cal. (500-yr moving window)

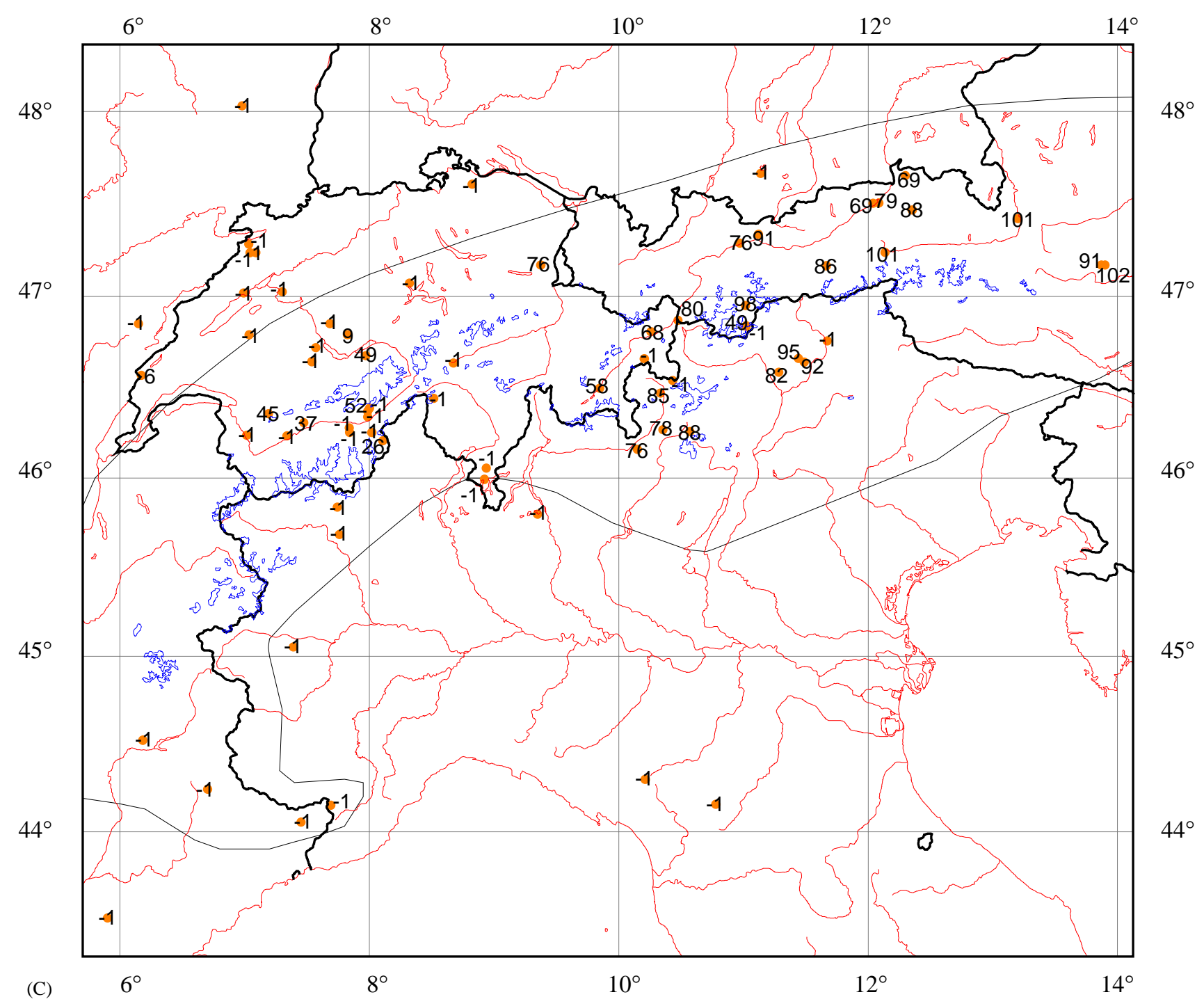

Fig. 4. (Continued)

negative statistical relationship and statistical significance or not are mostly similar for the steps of pollenpercentage thresholds from $0.5 \%$ to $8 \%$. In other words, the statistical results are relatively independent of the level of pollen-percentage threshold chosen. The choice of the pollen-percentage threshold used is therefore not that important for the study of spatial patterns (or direction) in migration and/or population expansion. The timing of reconstructed migration and of reconstructed population expansion, however, does depend on the threshold chosen. This result is nevertheless encouraging, because it indicates that the method of using pollen-percentage thresholds has some robustness with regard to spatial patterns. In this perspective, the use of $4 \%$ pollen for Picea by Ravazzi (2002) and 2-5\% by Burga and Perret (1998) to track Picea migration directions are good choices.
Today most trees have an altitudinal distribution of maximum abundance at a certain elevation and decreasing abundances at both higher and lower elevations. The trees studied have their maximum abundances today at elevations increasing in the sequence Quercus (colline zone)-Fagus (colline and montane zones)-Abies (montane and lower sub-alpine zones)-Picea (montane and sub-alpine zones) (Landolt, 1983). Provided that the present-day altitudinal abundance reflects the ecological optimum of each tree (past and present), it is possible that tree migration was faster and/or population expansion stronger at optimum elevation and slower both at lower and at higher elevation, rather than linear relationships with elevation. Inadequacy of linear regression with elevation is indicated in Table 2 by the scarcity of $P$-values $<0.05$ for Abies, Picea, and Fagus. The situation may be 
Quercus: $\geq 0.5 \%$ pollen; centuries BP cal. (500-yr moving window)



Fig. 5. Quercus; threshold $0.5 \%$. See caption to Fig. 2 for explanation.

different for Quercus, as this tree has its optimum today at a low elevation comparable to the elevation of the lower-lying sites studied.

\subsubsection{Abies (Figs. 2, 9, 10)}

Migration: The positive significant linear relationships between Abies pollen-percentage threshold ages cal BP and latitude (Table 2) indicate a northward movement of the tree in the course of time. This is also apparent from the map (Fig. 2) and the graphs (Fig. 9). In the latter, the southernmost lengthwise geographic segment 1 shows an early increase, the intermediate segments show intermediate increases, but they are hardly differentiated among each other, and the northernmost lengthwise segment 8 shows a late increase. Fig. 2 shows that the earliest points lay in central South Switzerland $\left(46.0-46.5^{\circ} \mathrm{N}, 8-9^{\circ} \mathrm{E}\right)$. This region marks therefore the immigration of Abies into the Swiss Alps from the south, approximately via Ticino and Simplon Pass (app. $9-10^{\circ} \mathrm{E}$ ). Some of the decisive data points lay close to the southern margin of the Alps (ca. $46^{\circ} \mathrm{N}, 9^{\circ} \mathrm{E}$ ), whereas sites in such a position are lacking for a long stretch both east and west of central South Switzerland. Therefore, even if there have been other immigration routes of Abies northward into the (presumably Italian) Alps, they are not recorded in the data available. The lengthwise geographic segments 2 and 3 show lower Abies percentages, indicating weaker population expansion than adjacent segments (Fig. 9). Segments 2 and 3 cover the inner-Alpine dry valleys in which Abies is rare (western Alps, e.g., Valais) or absent (eastern Alps, e.g., Engadin, upper Inn-valley) today. These environments were apparently always less suited for Abies than the peripheral, wetter parts of the Alps. The northward 
migration of Abies may therefore have taken routes around the two inner-Alpine areas rather than through them. The map Fig. 2 may suggest a northward migration route of Abies through the Alps between the two inner-Alpine areas (app. $9-10^{\circ} \mathrm{E}$ ), but it cannot prove it due to scarcity of data points along the northern edge of the Alps.

The relationships of Abies with longitude (W-E direction) are less strong than with latitude (Table 2). In simple linear regression between pollen-percentage threshold ages cal BP and longitude, statistical relationships are mostly significant and positive, but the significance is lower (higher $P$-values) than with latitude, and in multiple linear regression the relationships with longitude are not significant. These results indicate a weakly pronounced eastward trend. The lack of data points for most of the southern margin of the Alps, however, prevents us from explaining this in terms of tree migration.

Population expansion: Abies reached its highest abundance in West Switzerland (W of $8.5^{\circ} \mathrm{E}$ ), both in the Northern Alps and in the Jura Mountains. This reflects well its present-day abundance distribution.

\subsubsection{Fagus (Figs. 3, 6, 11, 12 )}

Migration: The results of Table 2 indicate a southward movement of Fagus in the course of time, but not an east- or westward movement. This would suggest that Fagus immigrated from the north into the Alps. For the reconstruction of Fagus migration in Switzerland, Burga and Perret (1998) used 5\% pollen to mark the beginning of mass population expansion shortly after immigration.

Fagus: expansion duration from 0.5 to $1 \%$ pollen (centuries)

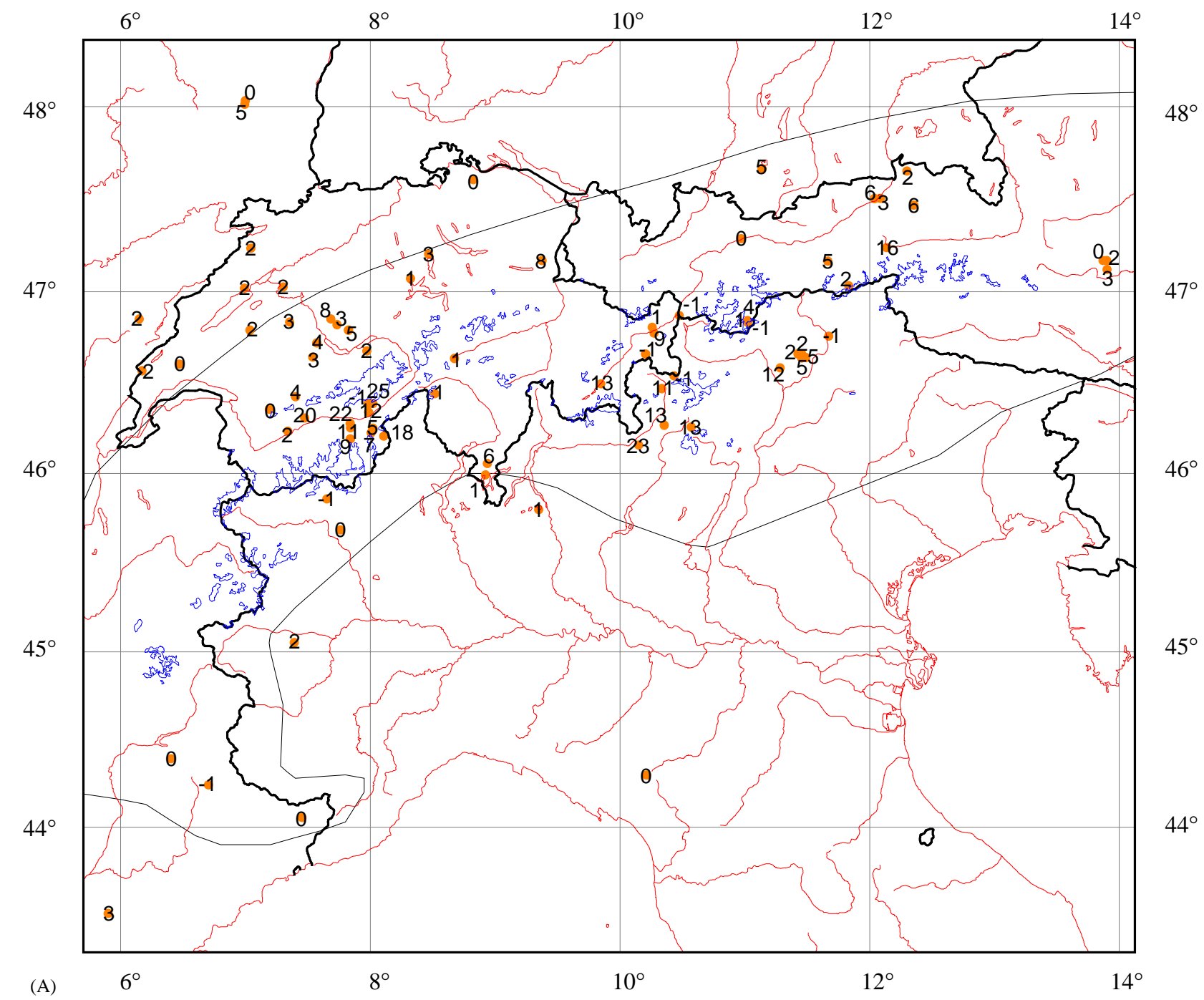

Fig. 6. (A) Fagus; thresholds $0.5-1 \%$, (B) Fagus; thresholds $8-16 \%$. Maps with pollen-percentage expansion duration in 100-yr classes (cal BP), calculated on the basis of moving time windows (see text for details): time elapsing between thresholds of $0.5-1 \%, 1-2 \%, 2-4 \%, 4-8 \%, 8-16 \%$, and 16-32\%; the selected maps shown have expansion durations with statistically significant relationships with longitude and/or latitude (see Table 3). 
Fagus: expansion duration from 8 to $16 \%$ pollen (centuries)

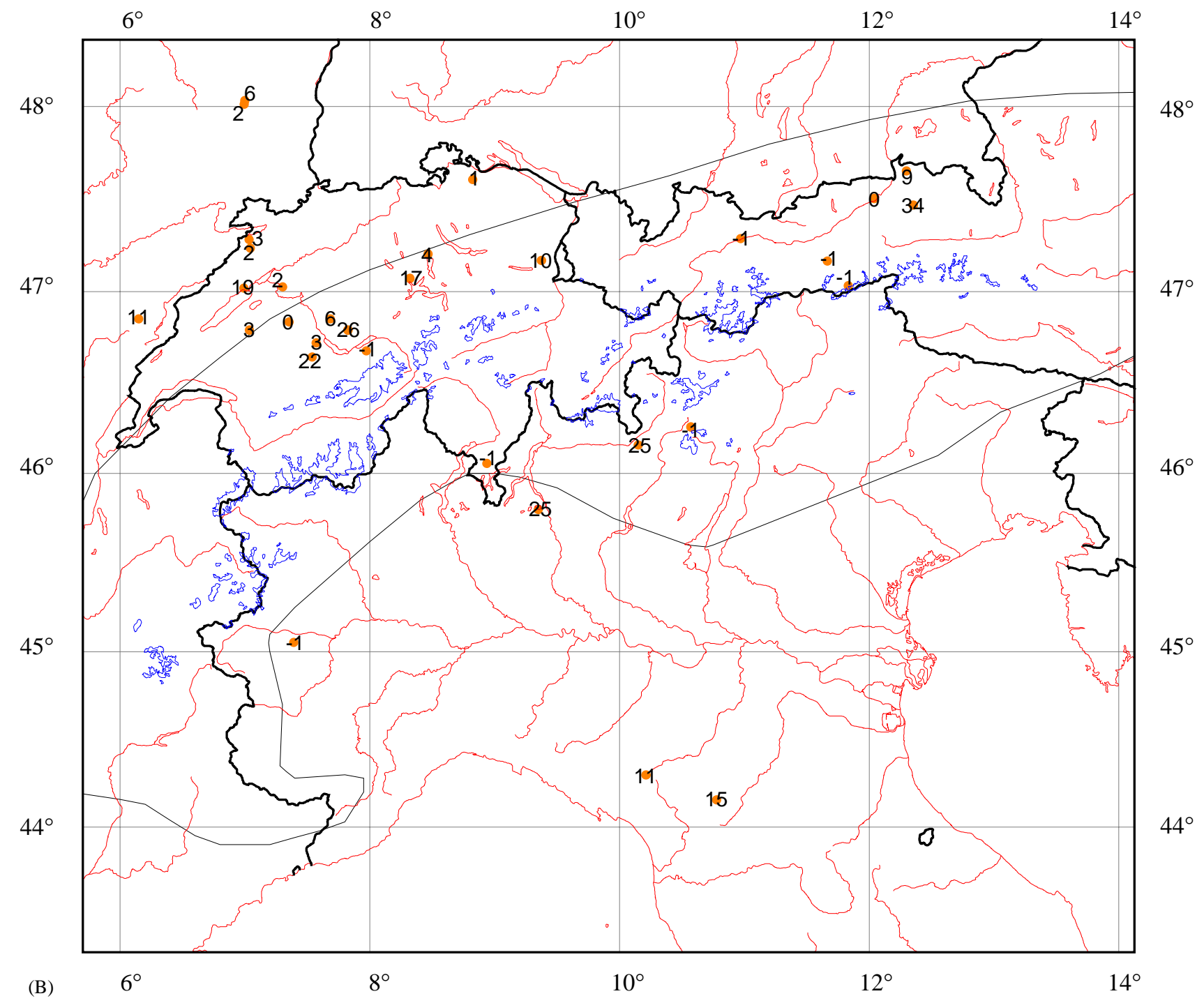

Fig. 6. (Continued)

However, in many pollen diagrams Fagus pollen shows a marked initial increase following a longish tail of scattered grains or low percentages. The interpretation of this tail determines how tree immigration should be separated from population expansion on the basis of pollen. A point of consideration is whether the tail reflects (a) the very slow building up of a tiny population until the population reaches a critical size enabling strong and rapid population expansion, (b) a tiny but stable population that expands only when circumstances change, or (c) pollen transported from remote populations that had expanded earlier. Human impact is frequently invoked as a cause for the rapid population expansion as indicated by the marked pollen increase, especially north of the Alps (see, e.g., Küster, 1997). Inside the Alps, however, the role of humans in the first population expansion is still a matter of speculation (see, e.g., Gardner and Willis, 1999; Küster, 1999). If human impact indeed has been the trigger for the first population expansion, but also if there has been a different trigger (such as climatic change, as postulated by Tinner and Lotter, 2001 for $8.2 \mathrm{cal}$ ka BP at two sites north of the Swiss Alps), the tree may have been locally present in small numbers for a long period of time but unable to expand in the absence of the trigger. In any case, the significance of the tail of scattered pollen grains or low percentages as an indication of the presence or absence of trees near the site should be decided on macrofossil evidence, which is, however, scarce or absent, so the significance of the tail remains unclear for the moment.

Population expansion: The negative significant linear relationships of Fagus with latitude indicate that the population expansion was earlier (Table 2) and faster 
(Table 3) in the north than in the south. This can also be observed on the map (Fig. 3). The graphs show that population expansion was much stronger north than south (Fig. 11, left), but as explained above they are not informative concerning tree migration. The smallest Fagus population expansion took place in lengthwise geographic segments 2 and 3 (Fig. 11) covering the inner-Alpine dry valleys, which indicates that these dry and continental environments were as unsuited for Fagus in the past as they are today. The statistical relationships with elevation suggest that the population expansion of Fagus was slower (Table 3) and likely also later (Table 2) with increasing elevation. This is in accordance with the present-day altitudinal distribution, since at lower elevation especially north of the Alps
Fagus dominates many forests, at middle elevation it grows well but mostly admixed with Abies, whereas at higher elevation it is mostly absent (Landolt, 1983).

\subsubsection{Picea (Figs. 4, 7, 13, 14)}

In contrast to Fagus, we must assume (in absence of indications to the contrary) that population expansion of Picea followed directly upon immigration independent of a trigger such as climatic shift or anthropogenic disturbance. A low pollen-percentage threshold marks therefore both the approximate immigration age and the beginning of population expansion. The negative significant linear relationships between Picea pollenpercentage threshold ages cal BP and longitude (Table 2) indicate that the tree migrated westward. Population

Picea: expansion duration from 2 to $4 \%$ pollen (centuries)

$6^{\circ}$



$10^{\circ}$

$12^{\circ}$

$14^{\circ}$

Fig. 7. (A) Picea; thresholds 2-4\%, (B) Picea; thresholds 16-32\%. Maps with pollen-percentage expansion duration in 100-yr classes (cal BP), calculated on the basis of moving time windows (see text for details): time elapsing between thresholds of $0.5-1 \%, 1-2 \%, 2-4 \%, 4-8 \%, 8-16 \%$, and 16-32\%; the selected maps shown have expansion durations with statistically significant relationships with longitude and/or latitude (see Table 3). 
Picea: expansion duration from 16 to $32 \%$ pollen (centuries)

$6^{\circ}$

$8^{\circ}$

$10^{\circ}$ $12^{\circ}$

$14^{\circ}$

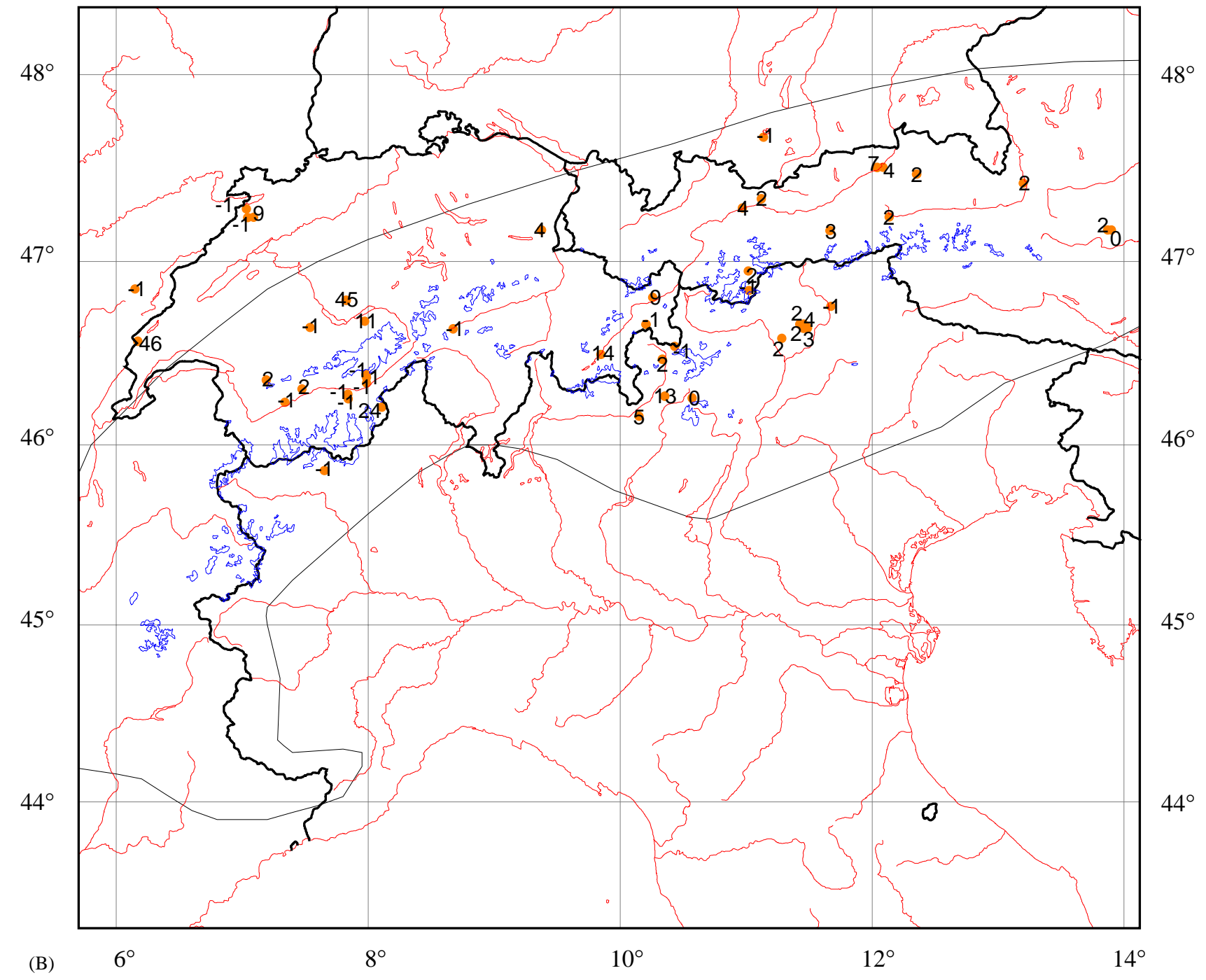

Fig. 7. (Continued)

expansion started therefore later in this direction, but it was also slower (Table 3). This is also apparent from the maps (Figs. 4A-C) and the graphs (Fig. 14). The graphs (Fig. 14) show that increasingly smaller populations built up towards the west. Fig. 4 seems to indicate that the westward migration was delayed around $10^{\circ} \mathrm{E}$, but scarcity of data points between $10^{\circ}$ and $9^{\circ} \mathrm{E}$ makes this uncertain. The mostly negative but rarely significant correlation between pollen-percentage threshold ages cal $\mathrm{BP}$ and elevation (Table 2) seem to suggest that tree migration and/or population-expansion progressed from high elevation downwards. Markgraf (1972) came to the same conclusion on the basis of five sites in Valais, a small region in the central Swiss Alps (sites 18, 21, 33, 34, and 37 in Fig. 1A). The correlation of Picea with latitude (Table 2) seems contradictory between simple and multiple linear regressions: positive in simple regression suggesting a southward movement, negative in multiple regression suggesting a northward movement. A speculative explanation is that the westward migration along the Alps caused automatically a slight southward migration due to the southwestcurved Alpine arch, which led to positive correlation in simple linear regression with latitude, whereas in multiple linear regression the westward movement is accounted for by the strong correlation with longitude, so that the possibly 'true' northward movement can emerge.

Our data are insufficient to decide whether the migration of Picea into the Jura Mountains took place via a northern route or a southern route or both. The westernmost data point on the maps (No. 1 on Fig. 1A) might support a southern route, but the support is weak because of moderate data quality (low pollen sums). 
Quercus: expansion duration from 4 to $8 \%$ pollen (centuries)

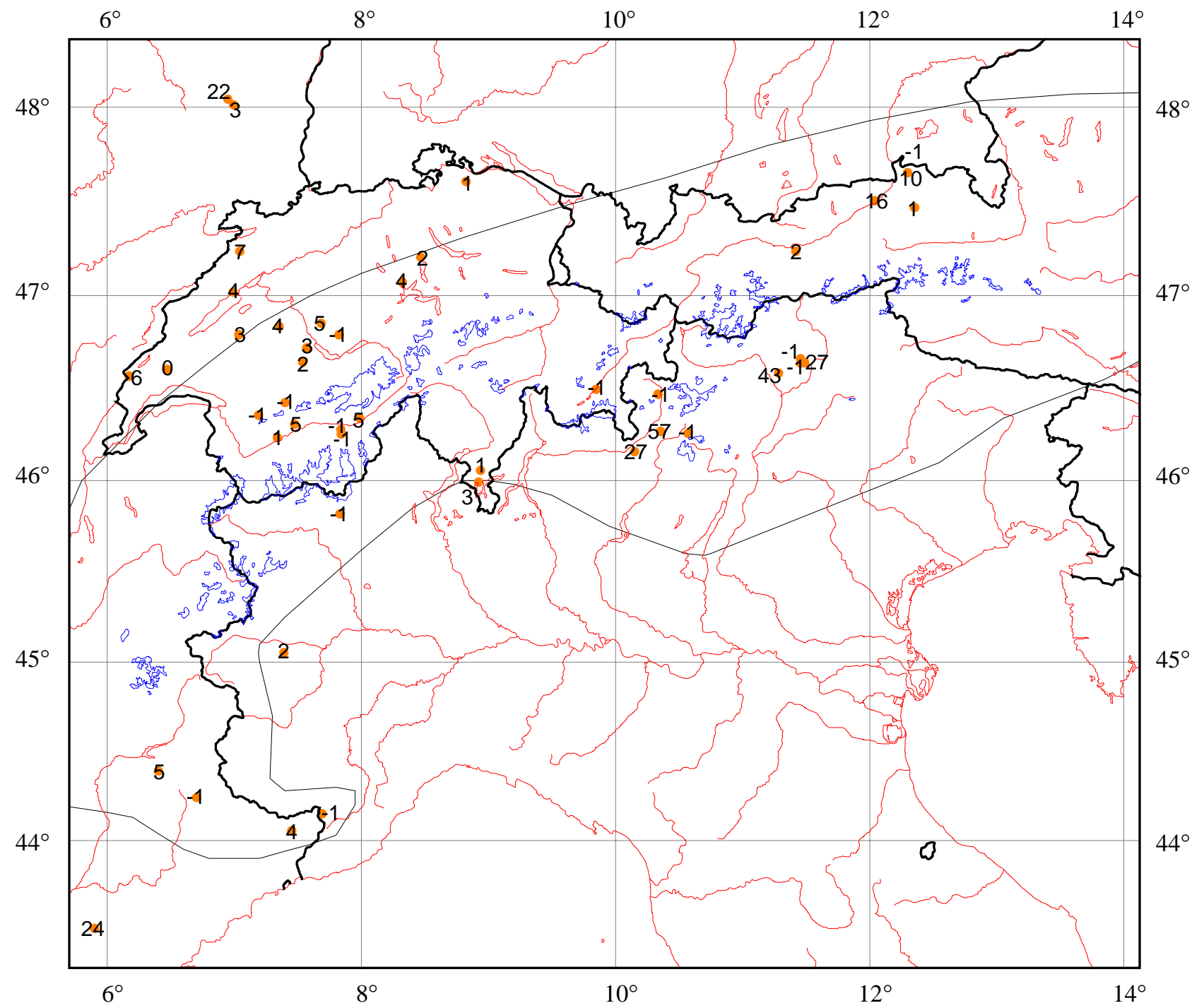

Fig. 8. Quercus; thresholds 4-8\%. Maps with pollen-percentage expansion duration in 100-yr classes (cal BP), calculated on the basis of moving time windows (see text for details): time elapsing between thresholds of $0.5-1 \%, 1-2 \%, 2-4 \%, 4-8 \%, 8-16 \%$, and $16-32 \%$; the selected maps shown have expansion durations with statistically significant relationships with longitude and/or latitude (see Table 3).

The youngest dates are located to the northwest in the Vosges Mountains. Picea in the Vosges Mountains may have originated either from the Black Forest lying to the east or from the Jura Mountains lying to the south.

\subsubsection{Quercus (Figs. 5, 8, 15, 16)}

Statistical relationships of Quercus pollen-percentage threshold ages cal BP with latitude or longitude (Table 2) are weak. They provide a weak indication that the tree migrated from south to north, which is also suggested by Figs. 5 and 15. The weakness of this trend seems to contrast with the clear south-to-north migration of Quercus on a European scale reconstructed by Brewer et al. (2002). This is only partially explained by the difference in scale, including the smaller distances of migration in the Alps combined with a high speed of migration. An additional explanation lies in the ambiguity of Quercus pollen percentages in terms of absence or presence of trees. In several sites thresholds up to $2 \%$ are crossed already in the Late Glacial. The significance of such thresholds in terms of absence/ presence of trees near the site is ambiguous, because the high pollen production and effective long-distance pollen transport of Quercus in a period with restricted local vegetation (especially at high-elevation sites) make it uncertain whether or not oaks grew near the site even with such pollen percentages. Quercus pollen production and percentages may also have fluctuated during the Late Glacial parallel to fluctuations in temperature, as has been shown for a mountain area in the western 


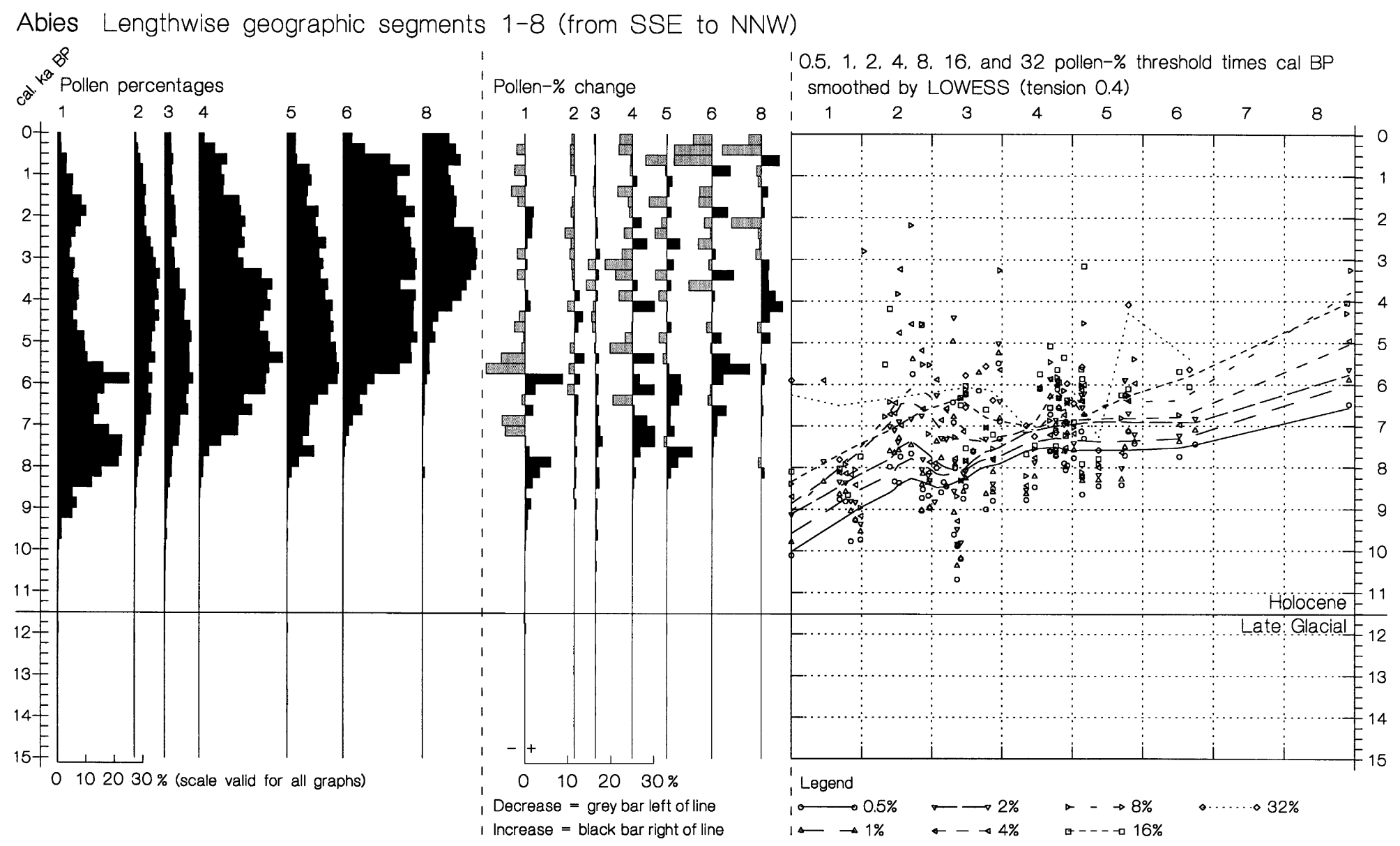

Fig. 9. Abies; summary of pollen data in lengthwise geographic segments. Data used lie in the area delimited by $45.5-48.1^{\circ} \mathrm{N}$ and $6-14^{\circ} \mathrm{E}$ (Fig. 1C). Horizontal line at $11.5 \mathrm{cal}$ ka BP marks Late Glacial-Holocene boundary. Left: Average pollen \% in 250-yr time slices (calibrated) in lengthwise geographic segments (explanation see text); calculation see text. Centre: Average pollenpercentage change per 250 year (calibrated) in the same geographic segments; calculation see text (section 3.6). Right: Pollen-percentage threshold ages cal BP in the same geographic segments scaled along transverse geographic axis smoothed by LOWESS tension 0.4; Cases of threshold-never-reached are not shown. 
Abies Transverse geographic segments 1-8 (from WSW to ENE)

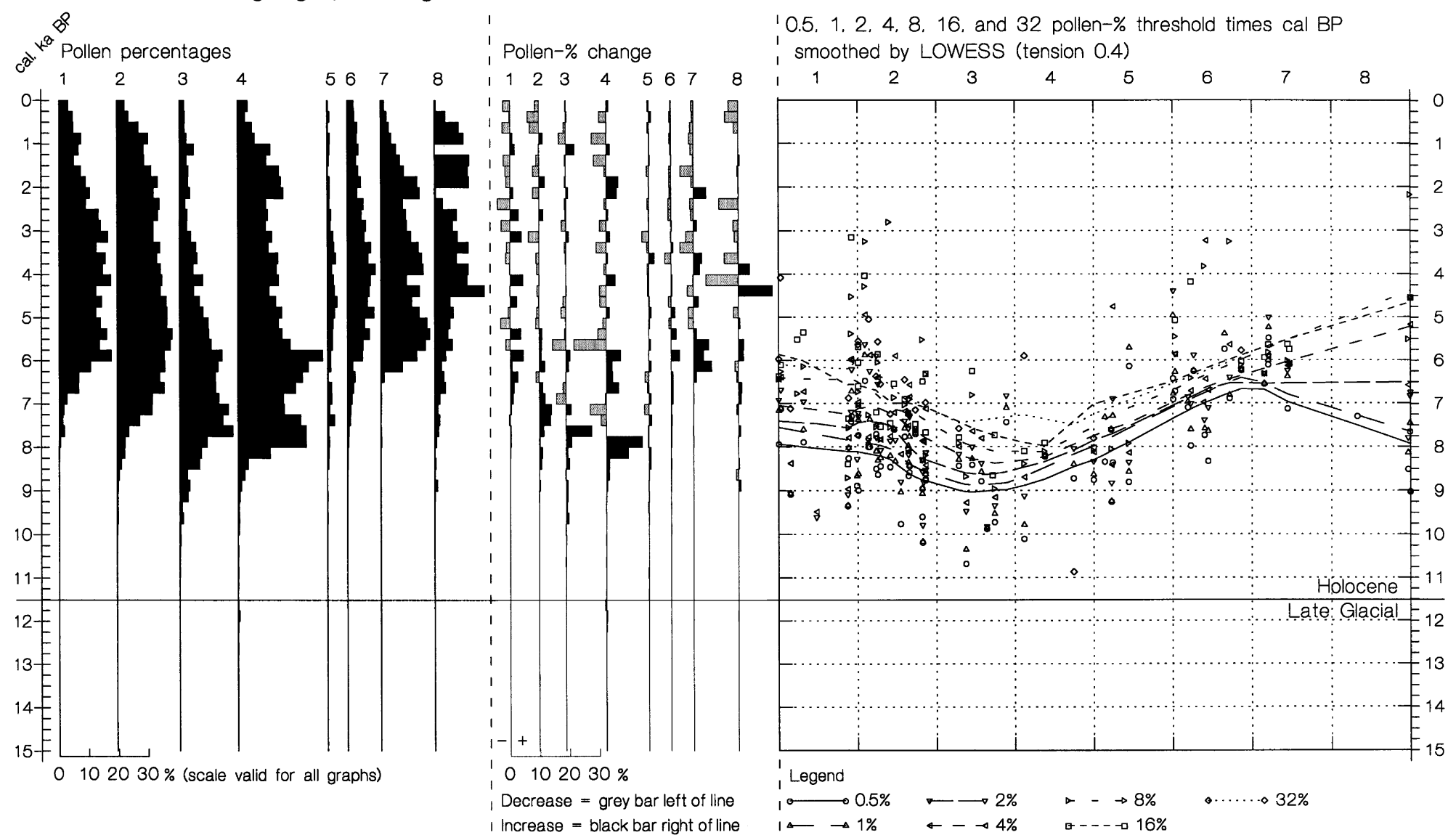

Fig. 10. Abies; summary of pollen data in tranverse geographic segments. Data used lie in the area delimited by $45.5-48.1^{\circ} \mathrm{N}$ and $6-14^{\circ} \mathrm{E}(\mathrm{Fig}$. $1 \mathrm{C}$ ). Horizontal line at 11.5 cal ka BP marks Late Glacial - Holocene boundary. Left: Average pollen \% in 250-yr time slices (calibrated) in tranverse geographic segments (explanation see text); calculation see text. Centre: Average pollen-percentage change per 250 year (calibrated) in the same geographic segments; calculation see text (Section 3.6). Right: Pollen-percentage threshold ages cal BP in the same geographic segments scaled along lengthwise geographic axis smoothed by LOWESS tension 0.4; Cases of threshold-never-reached are not shown. 
Fagus Lengthwise geographic segments 1-8 (from SSE to NNW)

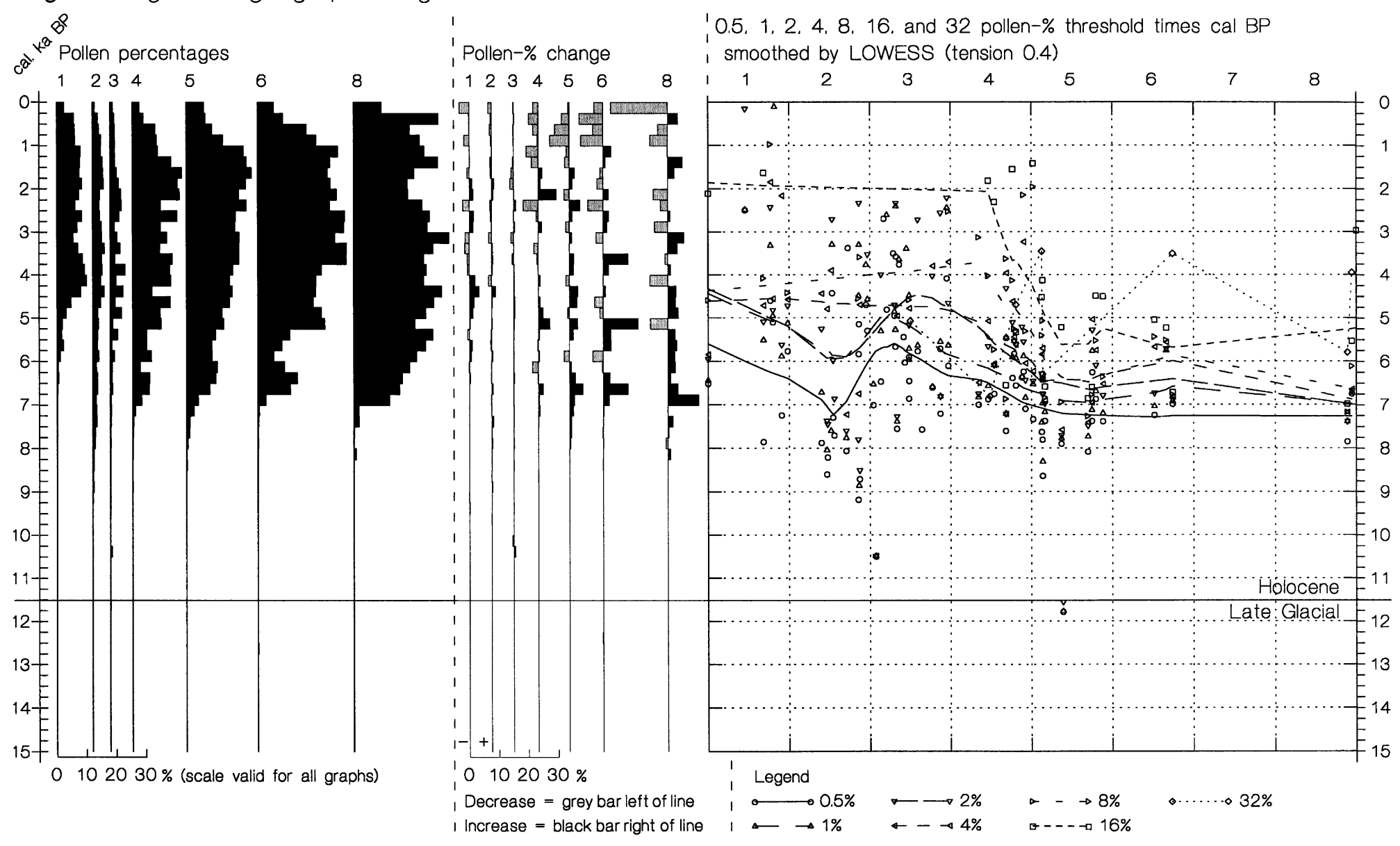

Fig. 11. Fagus; summary of pollen data in lengthwise geographic segments. See caption of Fig. 9 for explanation. 
Fagus Transverse geographic segments 1-8 (from WSW to ENE)

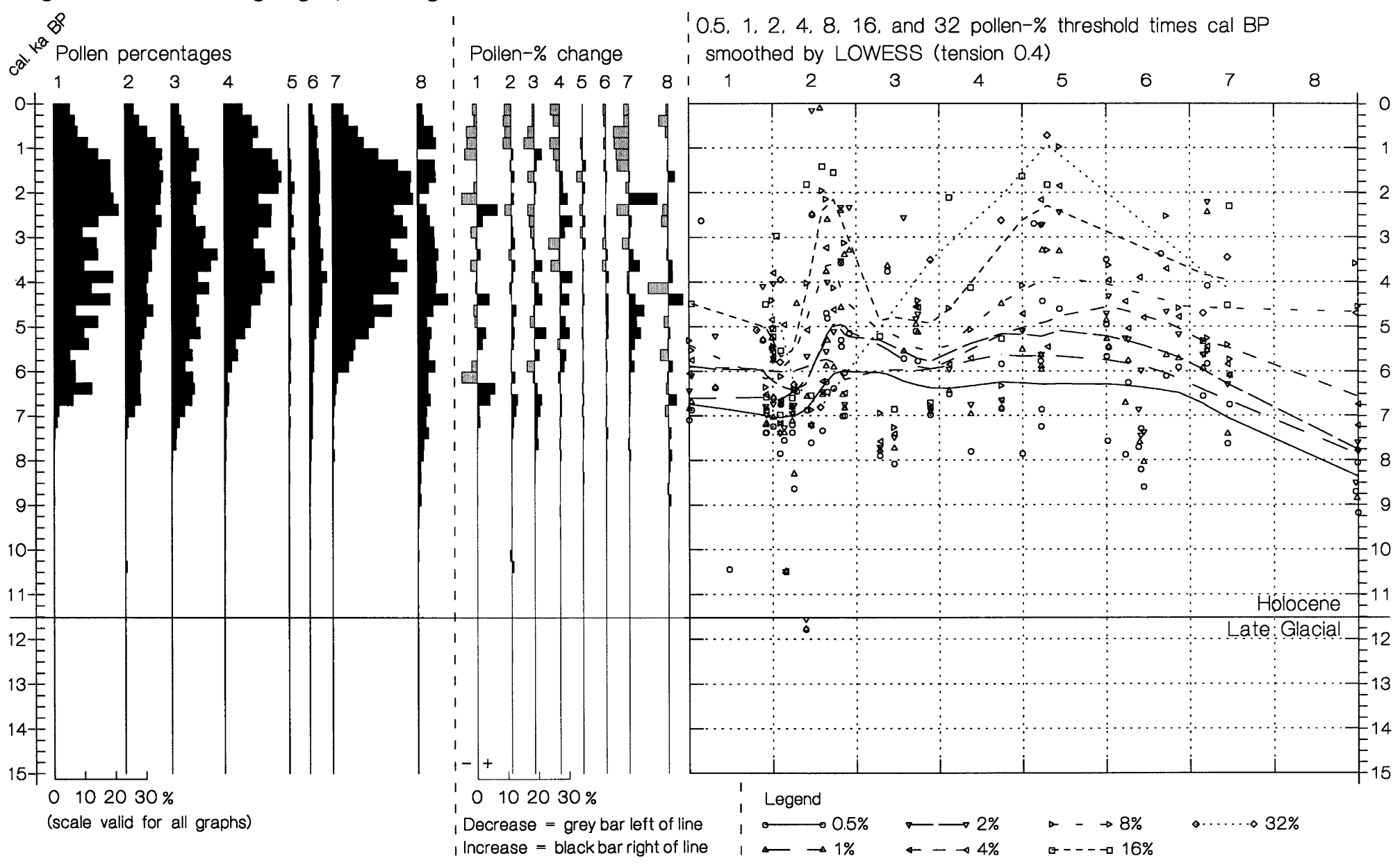

Fig. 12. Fagus; summary of pollen data in tranverse geographic segments. See caption of Fig. 10 for explanation. 
Picea Lengthwise geographic segments 1-8 (from SSE to NNW)

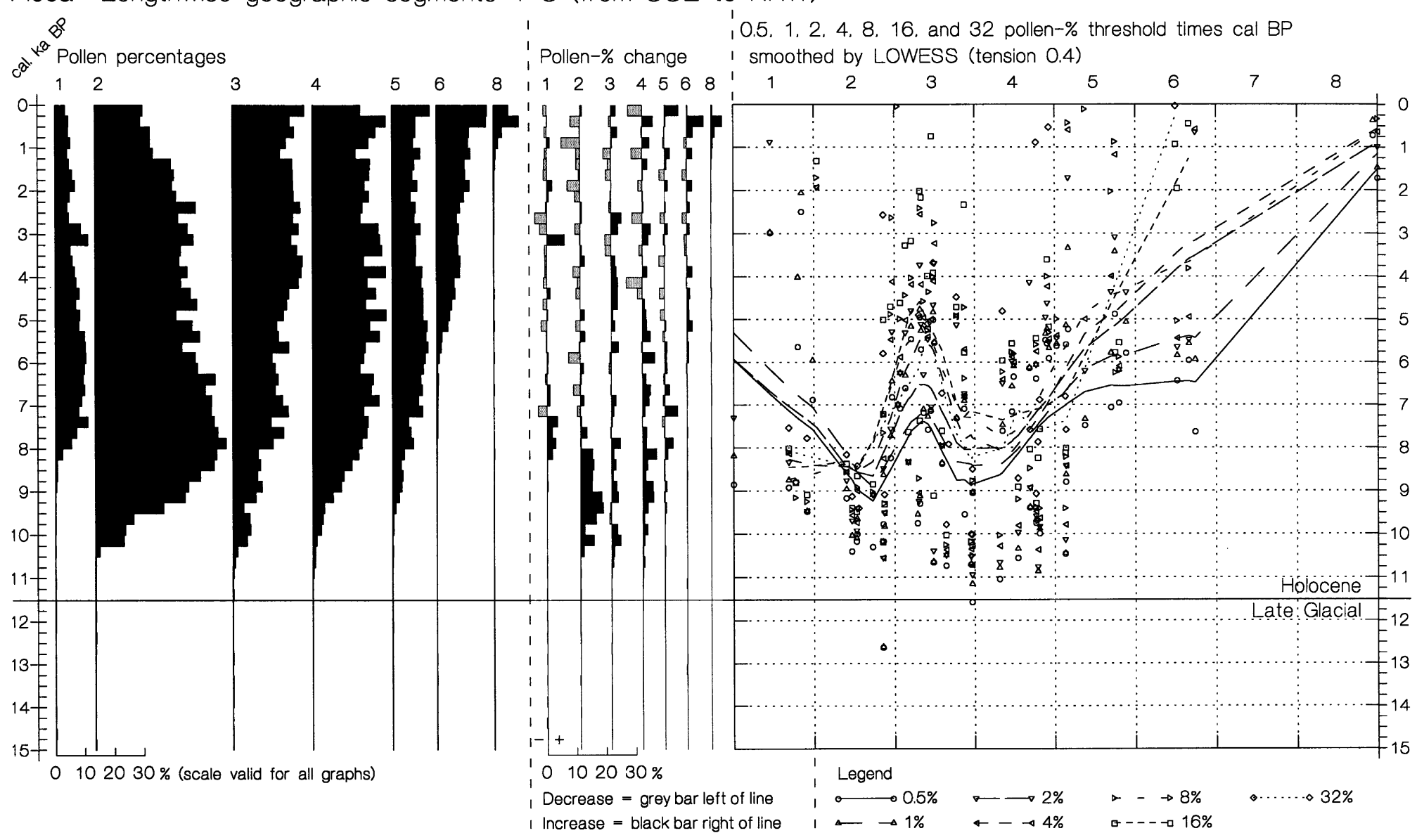

Fig. 13. Picea; summary of pollen data in lengthwise geographic segments. See caption of Fig. 9 for explanation. 
Picea Transverse geographic segments 1-8 (from WSW to ENE)

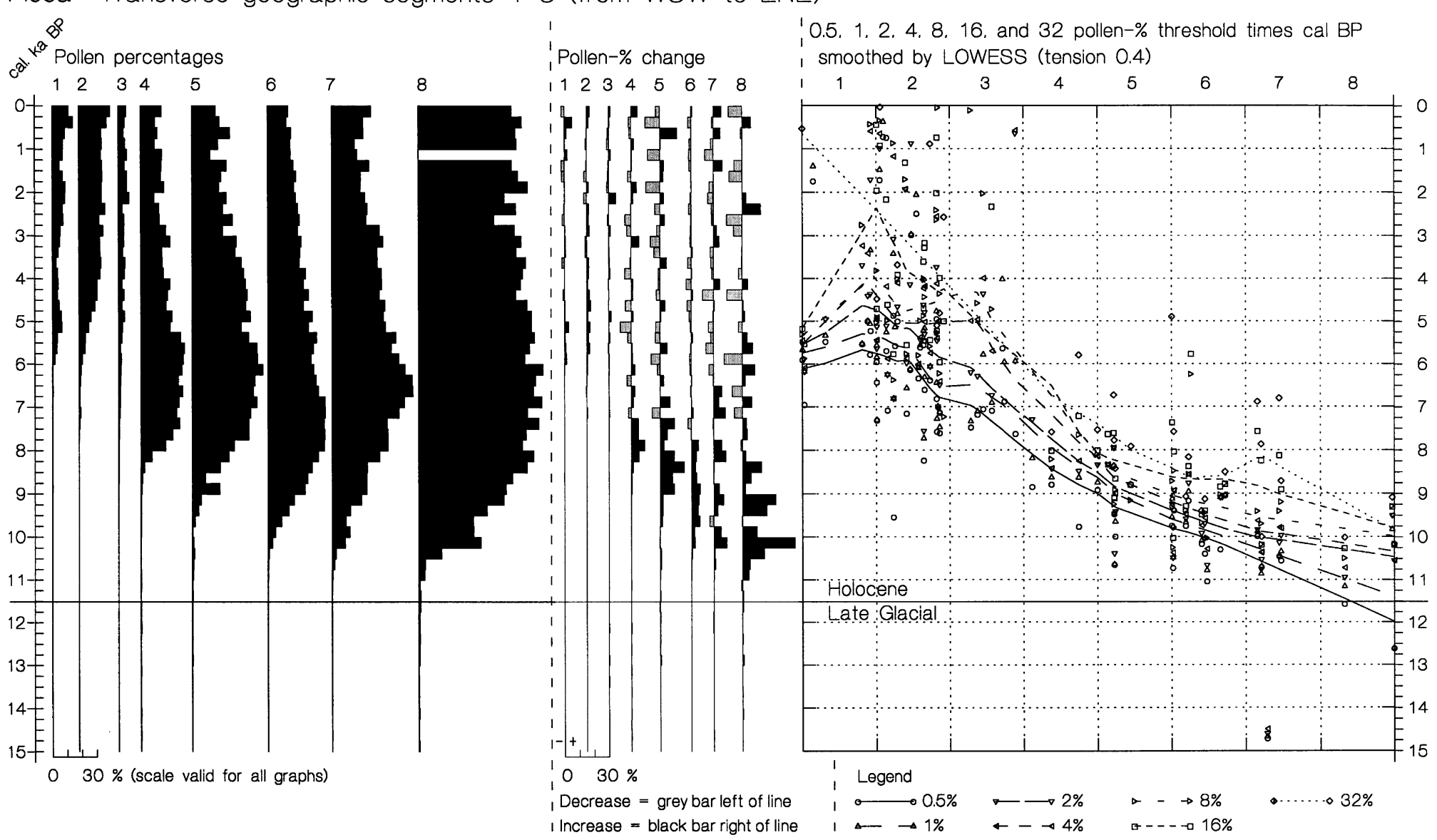

Fig. 14. Picea; summary of pollen data in tranverse geographic segments. See caption of Fig. 10 for explanation. 
Quercus Lengthwise geographic segments 1-8 (from SSE to NNW)

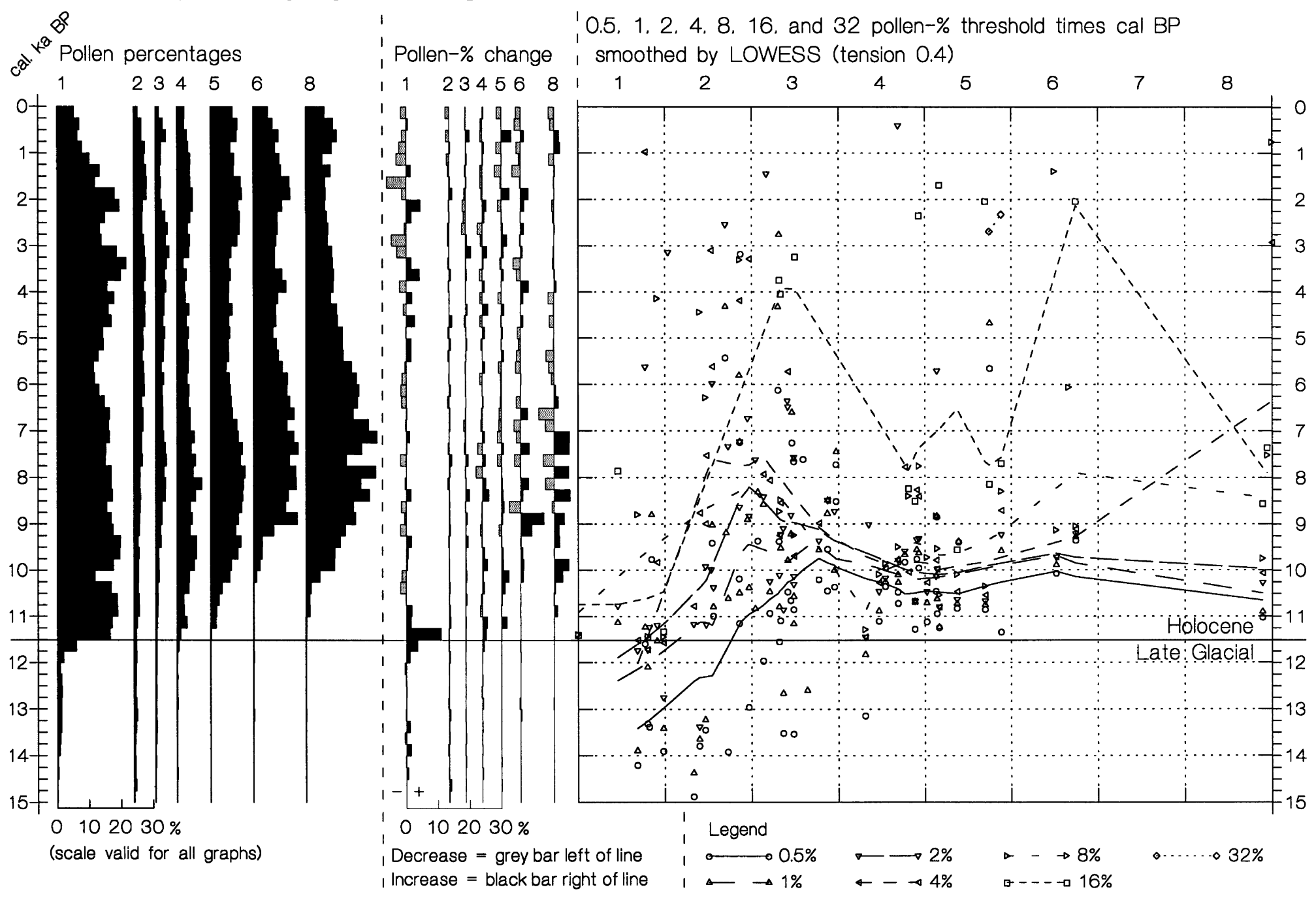

Fig. 15. Quercus; summary of pollen data in lengthwise geographic segments. See caption of Fig. 9 for explanation. 
Quercus Transverse geographic segments 1-8 (from WSW to ENE)



Fig. 16. Quercus; summary of pollen data in tranverse geographic segments. See caption of Fig. 10 for explanation. 
Population-expansion durations

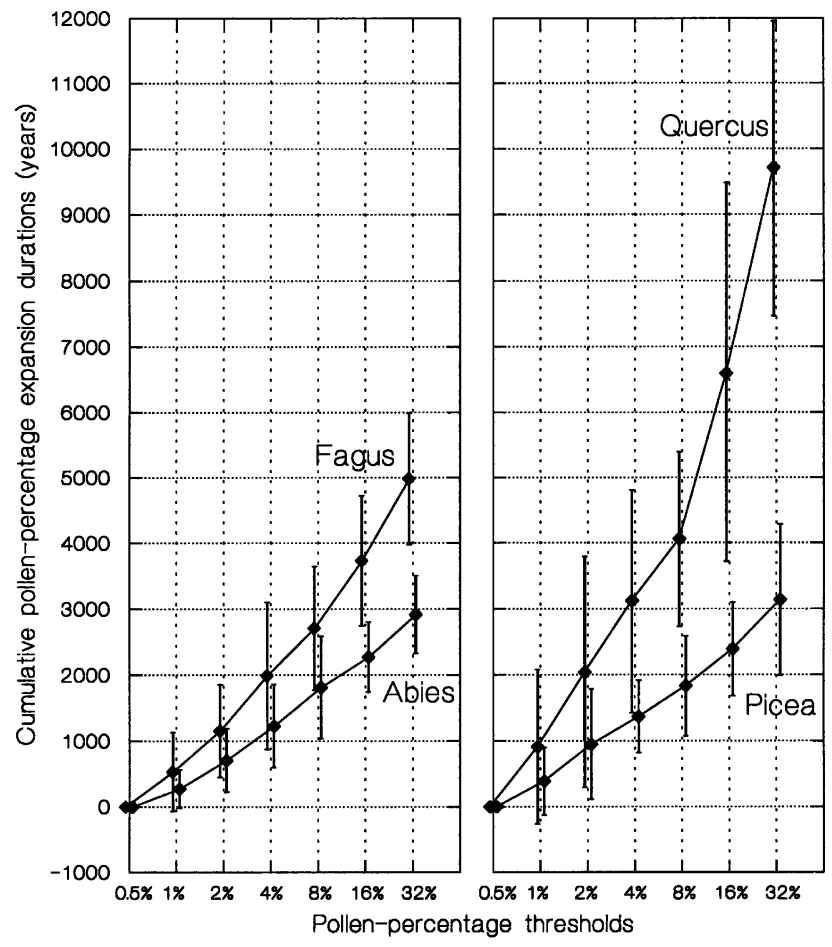

Fig. 17. Cumulative doubling times of pollen percentages. $X$-axis shows thresholds to which the pollen-percentages are doubled (e.g., $1 \%$ represents doubling from 0.5 to $1 \%, 2 \%$ is $1-2 \%$, etc.). $Y$-axis shows cumulative average duration in years of doubling of pollenpercentages with $1 \sigma$ error bars starting from $0.5 \%$; number of records for each pollen-percentage doubling is listed in Table 3. Average doubling times of pollen percentages are calculated using all threshold intervals as follows: Abies $0.45 \pm 0.56 \mathrm{ka}(N=306)$; Fagus $0.72 \pm$ $0.86 \mathrm{ka}(N=251)$; Picea $0.50 \pm 0.74 \mathrm{ka}(N=339)$; and Quercus $1.22 \pm$ $1.77 \mathrm{ka}(N=213)$.

Mediterranean (van der Knaap and van Leeuwen, 1997, p. 248). It can therefore not be excluded that oaks have migrated to the vicinity of several sites prior to the study period (the last $15 \mathrm{cal} \mathrm{ka} \mathrm{BP}$ ).

Quercus pollen has low percentages throughout the Holocene in lengthwise geographic segments 2 and 3 (Fig. 15) covering the inner-Alpine dry valleys. Quercus trees are abundant at lower elevation in western, but not in eastern inner-Alpine valleys today. Average 250-year time-slice pollen percentages in the few sites that lay below $1100 \mathrm{~m}$ elevation indicate that the situation was the same also in the past. Such percentages are in many cases above $10-15 \%$ in low-lying western inner-Alpine sites (Sites 6, 16, and 38 in Fig. 1A), whereas they are in all cases below $2-5 \%$ in low-lying eastern-Alpine sites (78 and 85 in Fig. 1A).

The statistical relationships indicate unambiguously that the Quercus population expansion was earlier (Table 2) and faster (Table 3) at low than at high elevation. This agrees with the present-day optimum of Quercus trees at lower elevation.

\subsection{Population expansion in relation to age (Table 4,} Figs. 9-17)

The speed of population expansion in relation to expansion age is explored in Table 4.

Abies has five cases of positive statistically significant correlation (Table 4), implying that population expansion was faster around sites where it had started later. We may tentatively connect this with the character of Abies as a climax tree; the gradual development of the forests from 9 to $5 \mathrm{cal} \mathrm{ka} \mathrm{BP}$ (when the majority of immigration and population expansion took place; see Figs. 9 and 10, right), especially soil maturation, may have favoured Abies population expansion.

Fagus has three cases of negative statistically significant correlation (Table 4), implying that population expansion was slower around sites where it had started later. About two-thirds of the Fagus immigration and population expansion took place between 8 and $5 \mathrm{cal} \mathrm{ka}$ BP (see Figs. 11 and 12, right), prior to notable human impact on the landscape, when the majority of tree species had already immigrated and some had completed their population expansion, whereas others were still in the process of expansion. Competition with an increasing number of other tree species may therefore have contributed to the slower Fagus population expansion starting later. About one-third of the Fagus immigration and population expansion took place after $5 \mathrm{cal}$ ka BP. Human impact on the landscape was steadily increasing in this period, which may have caused the Fagus population expansion to slow down. This is in agreement with the hypothesis of Küster (1997) that the transition from a shifting pattern of farming to permanent farming is not favourable for the expansion of Fagus.

Picea has eight cases of negative statistically significant correlation (Table 4), implying that population expansion was slower around sites where it had started later. Most of the Picea immigration and much of its population expansion took place during the first half of the Holocene (see Figs. 13 and 14, right), in which period many other tree species also immigrated and expanded. One explanation could therefore be that Picea has advantages as a pioneer tree, expanding faster in the absence of competitors and slower when other tree species had immigrated. Some of the Picea immigration and population expansion took place after 5 cal ka BP, when, similar to the case of Fagus, increasing human impact may have slowed down the process more and more. An alternative explanation may be that the climate turned less favourable for Picea, either in course of time or spatially from east to west coinciding with the direction of migration.

Quercus has three cases of positive statistically significant correlation (Table 4), implying that population expansion was faster around sites where it had 
Table 2

Linear regression of pollen-percentage threshold age cal BP of Abies, Fagus, Picea, and Quercus versus Latitude, Longitude, and Elevation ${ }^{\text {a }}$

\begin{tabular}{|c|c|c|c|c|c|c|c|c|c|c|}
\hline \multicolumn{3}{|l|}{ Data } & \multirow{2}{*}{\multicolumn{3}{|c|}{$\begin{array}{l}\text { Simple linear regression } \\
\text { Positive/negative correlation and } \\
P \text {-value }\end{array}$}} & \multicolumn{5}{|c|}{ Multiple linear regression after step-wise forward selection } \\
\hline \multirow[b]{2}{*}{ Tree } & \multirow[b]{2}{*}{$\begin{array}{l}\text { Threshold } \\
(\%)\end{array}$} & \multirow[b]{2}{*}{$\begin{array}{l}\text { No. of } \\
\text { records }\end{array}$} & & & & \multicolumn{3}{|c|}{$\begin{array}{l}\text { Positive/negative correlation and } \\
P \text {-value }\end{array}$} & \multirow[b]{2}{*}{$P$-value } & \multirow[b]{2}{*}{$\begin{array}{l}\text { Adjusted } \\
\text { multiple } R^{2}\end{array}$} \\
\hline & & & $\begin{array}{l}\text { Latitude } \\
(\mathrm{S} \rightarrow \mathrm{N})\end{array}$ & $\begin{array}{l}\text { Longitude } \\
(\mathrm{W} \rightarrow \mathrm{E})\end{array}$ & $\begin{array}{l}\text { Elevation } \\
(\uparrow)\end{array}$ & $\begin{array}{l}\text { Latitude } \\
(\mathrm{S} \rightarrow \mathrm{N})\end{array}$ & $\begin{array}{l}\text { Longitude } \\
(\mathrm{W} \rightarrow \mathrm{E})\end{array}$ & $\begin{array}{l}\text { Elevation } \\
(\uparrow)\end{array}$ & & \\
\hline \multirow[t]{7}{*}{ Abies } & 0.5 & 68 & +0.000 & +0.007 & -0.236 & +0.000 & & & 0.000 & 0.490 \\
\hline & 1 & 68 & +0.000 & +0.011 & -0.543 & +0.000 & & & 0.000 & 0.414 \\
\hline & 2 & 65 & +0.000 & +0.025 & -0.528 & +0.000 & & & 0.000 & 0.408 \\
\hline & 4 & 55 & +0.000 & $+\mathbf{0 . 0 1 5}$ & -0.948 & +0.001 & +0.126 & & 0.000 & 0.259 \\
\hline & 8 & 47 & +0.003 & +0.040 & +0.174 & +0.000 & & +0.007 & 0.000 & 0.274 \\
\hline & 16 & 35 & +0.003 & +0.397 & +0.901 & +0.003 & & & 0.003 & 0.214 \\
\hline & 32 & 16 & +0.649 & -0.224 & -0.781 & & & & & 0.000 \\
\hline \multirow{7}{*}{ Fagus } & 0.5 & 71 & -0.003 & -0.633 & +0.108 & -0.003 & & & 0.003 & 0.105 \\
\hline & 1 & 66 & -0.000 & -0.295 & +0.089 & -0.000 & & & 0.000 & 0.211 \\
\hline & 2 & 56 & -0.001 & -0.757 & +0.071 & -0.001 & & +0.102 & 0.001 & 0.200 \\
\hline & 4 & 44 & -0.003 & +0.100 & +0.001 & -0.001 & & +0.000 & 0.000 & 0.391 \\
\hline & 8 & 33 & $-\mathbf{0 . 0 2 0}$ & +0.080 & +0.000 & -0.002 & +0.144 & +0.000 & 0.000 & 0.501 \\
\hline & 16 & 23 & -0.060 & +0.260 & +0.070 & -0.012 & +0.090 & +0.011 & 0.008 & 0.366 \\
\hline & 32 & 9 & +0.189 & +0.310 & +0.757 & & & & & 0.000 \\
\hline \multirow[t]{7}{*}{ Picea } & 0.5 & 69 & -0.476 & -0.000 & -0.078 & +0.058 & -0.000 & & 0.000 & 0.708 \\
\hline & 1 & 71 & -0.297 & -0.000 & -0.049 & +0.046 & -0.000 & & 0.000 & 0.728 \\
\hline & 2 & 69 & -0.135 & -0.000 & -0.030 & & -0.000 & -0.049 & 0.000 & 0.691 \\
\hline & 4 & 62 & -0.197 & -0.000 & -0.140 & +0.020 & -0.000 & & 0.000 & 0.728 \\
\hline & 8 & 64 & -0.030 & -0.000 & -0.274 & & -0.000 & & 0.000 & 0.667 \\
\hline & 16 & 53 & -0.010 & -0.000 & -0.986 & & -0.000 & & 0.000 & 0.685 \\
\hline & 32 & 34 & -0.125 & -0.000 & -0.443 & +0.009 & -0.000 & & 0.000 & 0.762 \\
\hline \multirow[t]{7}{*}{ Quercus } & 0.5 & 63 & +0.000 & +0.047 & +0.002 & +0.000 & & +0.000 & 0.000 & 0.415 \\
\hline & 1 & 63 & +0.076 & +0.164 & +0.000 & +0.000 & -0.134 & +0.000 & 0.000 & 0.359 \\
\hline & 2 & 59 & +0.832 & +0.333 & +0.002 & +0.101 & & +0.001 & 0.002 & 0.165 \\
\hline & 4 & 41 & -0.744 & +0.556 & $+\mathbf{0 . 0 0 0}$ & +0.102 & & +0.000 & 0.000 & 0.304 \\
\hline & 8 & 32 & +0.264 & -0.749 & +0.000 & +0.073 & & +0.000 & 0.000 & 0.378 \\
\hline & 16 & 19 & +0.449 & -0.179 & +0.251 & & & & & 0.000 \\
\hline & 32 & 2 & & & & & & & & \\
\hline
\end{tabular}

${ }^{a}$ Sites used lie $45.5-48.1^{\circ} \mathrm{N}, 6-14^{\circ} \mathrm{E}$. Calculation of pollen-percentage threshold age cal BP is explained in text. No. of records is the number of sites in which the pollen-percentage threshold is crossed. Latitude and longitude are in Greenwich coordinates. Positive or negative correlation are indicated by + or-preceding $P$-value; the signs of the correlations have been reversed in order to make the results easier understandable intuitively. Positive correlation for latitude indicates northward direction of migration or population expansion, for longitude eastward, and for elevation upward. Statistical significance $(P<0.05)$ in simple linear regression is indicated by bold print. In multiple linear regressions with stepwise forward selection, positive or negative correlation and $P$-value are given for selected factors only. Adjusted multiple $R^{2}$ is proportion of variance explained. Regression was not possible for Quercus $32 \%$ due to $N=2$.

started later. These three cases represent an early phase of Quercus expansion (recorded as pollen-percentage increase from $0.5-1 \%$ to $4-8 \%$ ), and one-quarter to one-third of the data points in each case have the beginning of the population expansion (lower pollenpercentage threshold) in the Late Glacial, whereas the remaining data points in these cases are of Holocene age (see Figs. 15 and 16, right). For the three statistically significant cases, therefore, the climatic amelioration at the beginning of the Holocene sufficiently explains that Quercus population expansion was faster around sites where it had started later. The results in Table 4 give no clues about speed of Quercus population expansion within the Holocene.

\section{Conclusions and discussion}

The method of using pollen-percentage thresholds for the reconstruction of directions of migration and population expansion appears to have some robustness, as results are mostly similar for different thresholds between $0.5 \%$ and $8 \%$. For the reconstruction of ages of arrival or migration, however, a pollen-percentage threshold appropriate for the taxon should be chosen. An appropriate choice should ideally be supported by combined pollen-macrofossil studies. The results of modern pollen surface samples in combination with contemporary geographical distribution of trees may also be helpful, though only to a small degree, because 
Table 3

Linear regression of pollen-percentage expansion duration of Abies, Fagus, Picea, and Quercus versus Latitude, Longitude, and Elevation ${ }^{\text {a }}$

\begin{tabular}{|c|c|c|c|c|c|c|c|c|c|c|}
\hline \multicolumn{3}{|l|}{ Data } & \multirow{2}{*}{\multicolumn{3}{|c|}{$\begin{array}{l}\text { Simple linear regression: } \\
\text { Positive/negative correlation and } \\
P \text {-value }\end{array}$}} & \multicolumn{5}{|c|}{ Multiple linear regression after stepwise forward selection: } \\
\hline \multirow[b]{2}{*}{ Tree } & \multirow[b]{2}{*}{$\begin{array}{l}\text { Threshold: } \\
\%\end{array}$} & \multirow[b]{2}{*}{$\begin{array}{l}\text { No. of } \\
\text { records }\end{array}$} & & & & $\begin{array}{l}\text { Positive } / \mathrm{n} \\
P \text {-value }\end{array}$ & ative correla & on and & & \multirow[b]{2}{*}{$\begin{array}{l}\text { Adjusted } \\
\text { multiple } R^{2}\end{array}$} \\
\hline & & & $\begin{array}{l}\text { Latitude } \\
(\mathrm{S} \rightarrow \mathrm{N})\end{array}$ & $\begin{array}{l}\text { Longitude } \\
(\mathrm{W} \rightarrow \mathrm{E})\end{array}$ & $\begin{array}{l}\text { Elevation } \\
(\uparrow)\end{array}$ & $\begin{array}{l}\text { Latitude } \\
(\mathrm{S} \rightarrow \mathrm{N})\end{array}$ & $\begin{array}{l}\text { Longitude } \\
(\mathrm{W} \rightarrow \mathrm{E})\end{array}$ & $\begin{array}{l}\text { Elevation } \\
(\uparrow)\end{array}$ & $P$-value & \\
\hline \multirow[t]{6}{*}{ Abies } & $0.5-1$ & 67 & -0.531 & -0.924 & +0.104 & & & +0.104 & 0.104 & 0.025 \\
\hline & $1-2$ & 64 & -0.388 & +0.635 & +0.172 & & & & & 0.000 \\
\hline & $2-4$ & 55 & -0.521 & +0.005 & +0.030 & & +0.111 & +0.062 & 0.027 & 0.096 \\
\hline & 4-8 & 44 & +0.625 & +0.096 & +0.008 & & & +0.008 & 0.008 & 0.135 \\
\hline & $8-16$ & 32 & -0.176 & -0.755 & +0.632 & & & & & 0.000 \\
\hline & $16-32$ & 16 & -0.045 & -0.525 & -0.392 & -0.045 & & & 0.045 & 0.204 \\
\hline \multirow[t]{6}{*}{ Fagus } & $0.5-1$ & 64 & $-\mathbf{0 . 0 1 0}$ & +0.999 & $+\mathbf{0 . 0 3 0}$ & -0.019 & & +0.061 & 0.006 & 0.126 \\
\hline & $1-2$ & 56 & -0.028 & -0.986 & +0.019 & -0.040 & & +0.027 & 0.008 & 0.137 \\
\hline & $2-4$ & 44 & -0.140 & $+\mathbf{0 . 0 3 5}$ & $+\mathbf{0 . 0 0 0}$ & -0.125 & & +0.000 & 0.001 & 0.264 \\
\hline & 4-8 & 32 & -0.192 & +0.619 & +0.022 & & & +0.022 & 0.022 & 0.135 \\
\hline & $8-16$ & 22 & -0.046 & +0.131 & +0.556 & -0.024 & +0.061 & & 0.024 & 0.255 \\
\hline & $16-32$ & 7 & +0.308 & -0.859 & -0.538 & & & & & 0.000 \\
\hline \multirow[t]{6}{*}{ Picea } & $0.5-1$ & 69 & -0.803 & -0.026 & -0.025 & & -0.062 & -0.059 & 0.014 & 0.094 \\
\hline & $1-2$ & 65 & -0.989 & -0.124 & -0.044 & & & -0.044 & 0.044 & 0.048 \\
\hline & $2-4$ & 62 & -0.062 & -0.004 & +0.910 & & -0.004 & & 0.004 & 0.116 \\
\hline & $4-8$ & 58 & +0.709 & -0.149 & -0.282 & & -0.149 & & 0.149 & 0.020 \\
\hline & $8-16$ & 49 & +0.384 & -0.194 & -0.532 & & & & & 0.000 \\
\hline & $16-32$ & 31 & -0.272 & -0.001 & -0.477 & & -0.001 & & 0.001 & 0.294 \\
\hline \multirow[t]{6}{*}{ Quercus } & $0.5-1$ & 56 & -0.546 & +0.086 & +0.020 & & & +0.020 & 0.020 & 0.080 \\
\hline & $1-2$ & 49 & -0.713 & +0.068 & +0.150 & & +0.068 & & 0.068 & 0.049 \\
\hline & $2-4$ & 38 & -0.087 & +0.041 & +0.001 & & +0.138 & +0.005 & 0.002 & 0.254 \\
\hline & 4-8 & 27 & -0.439 & +0.028 & +0.000 & & +0.056 & +0.000 & 0.000 & 0.619 \\
\hline & $8-16$ & 15 & +0.809 & -0.358 & +0.932 & & & & & 0.000 \\
\hline & $16-32$ & 2 & & & & & & & & \\
\hline
\end{tabular}

${ }^{a}$ Sites used lie $45.5-48.1^{\circ} \mathrm{N}, 6-14^{\circ} \mathrm{E}$. Pollen-percentage expansion duration is the time lapse between two consecutive pollen-percentage threshold ages cal BP. No. of records is the number of sites in which both pollen-percentage thresholds are crossed (also valid for Fig. 17). Latitude and longitude are in Greenwich coordinates. Positive or negative correlation are indicated by + or - preceding $P$-value. Positive correlation for latitude indicates northward trend (i.e., expansion duration increasing to the north), for longitude eastward, and for elevation upward. Statistical significance $(P<0.05)$ in simple linear regression is indicated by bold print. In multiple linear regressions with stepwise forward selection, positive or negative correlation and P-value are given for selected factors only. Adjusted multiple $R^{2}$ is proportion of variance explained. Regression was not possible for Quercus $16-32 \%$ due to $N=2$.

the modern, anthropogenic landscape, especially its openness, is rather different from the mainly forested landscape during the time of first arrival of the trees.

Linear regression is used to evaluate geographic trends (latitude, longitude, and elevation) in pollen data, but this may in some cases not match the trends, such as optimum of trees at middle elevation of, e.g., Abies and Picea.

Migration directions reconstructed in this paper for part of the Alps and surroundings $45.5-48.1^{\circ} \mathrm{N}, 6-14^{\circ} \mathrm{E}$ include a northward migration by Abies, southward by Fagus, westward by Picea, and northward by Quercus. The results do not suggest the presence of refuge areas of any of these trees in the region studied. The actual migrations may have been earlier than assessed on the basis of pollen, because there might be a time lapse between the first arrival of a tree and the first traceable population expansion. This time lapse might be considerable especially for Fagus in some parts of the study area. On a European scale, our results support migration reconstructions published earlier. In contrary, detailed movements of trees into and through the Alps, such as proposed by Burga and Perret (1998), Nakagawa (1998), and others, are not supported by our data or they do not emerge unambiguously. The northwestern Alps are rather well studied, but in other parts of the Alps there remains an extreme scarcity of high-quality data (well-dated pollen diagrams with a high temporal resolution), especially in a band along the southern margin of the Alps south of Austria and in the eastern Alps. New research should focus there in order to reconstruct the movement of trees into and across the Alps.

Abies: Results indicate that Abies migrated into the Alps from south to north. Abies may have entered the southern Alps at various points at different ages, but the scarcity of sites at the southern foot of the Alps does not allow us to reconstruct more than one, namely in central 
Table 4

Simple linear regression of pollen-percentage threshold age cal BP and pollen-expansion duration (= duration to higher threshold $)^{\mathrm{a}}$

\begin{tabular}{|c|c|c|c|c|c|c|c|c|c|c|c|c|c|}
\hline \multirow[t]{3}{*}{ Tree } & \multirow[b]{3}{*}{$\begin{array}{l}\text { Upper } \\
\text { threshold } \rightarrow\end{array}$} & \multicolumn{2}{|c|}{ Pos./neg. correlation } & \multicolumn{2}{|c|}{ Pos./neg. correlation } & \multicolumn{2}{|c|}{ Pos./neg. correlation } & \multicolumn{2}{|c|}{ Pos./neg. correlation } & \multicolumn{2}{|c|}{ Pos./neg. correlation } & \multicolumn{2}{|c|}{ Pos./neg. correlation } \\
\hline & & $P$-value & $\begin{array}{l}\text { Adjusted } \\
\text { multiple } R^{2}\end{array}$ & $P$-value & $\begin{array}{l}\text { Adjusted } \\
\text { multiple } R^{2}\end{array}$ & $P$-value & $\begin{array}{l}\text { Adjusted } \\
\text { multiple } R^{2}\end{array}$ & $P$-value & $\begin{array}{l}\text { Adjusted } \\
\text { multiple } R^{2}\end{array}$ & $P$-value & $\begin{array}{l}\text { Adjusted } \\
\text { multiple } R^{2}\end{array}$ & $P$-value & $\begin{array}{l}\text { Adjusted } \\
\text { multiple } R^{2}\end{array}$ \\
\hline & & \multicolumn{2}{|l|}{$32 \%$} & \multicolumn{2}{|l|}{$16 \%$} & \multicolumn{2}{|l|}{$8 \%$} & \multicolumn{2}{|l|}{$4 \%$} & \multicolumn{2}{|l|}{$2 \%$} & \multicolumn{2}{|l|}{$1 \%$} \\
\hline \multirow[t]{9}{*}{ Abies } & $\begin{array}{l}\text { Lower } \\
\text { threshold }\end{array}$ & & & & & & & & & & & & \\
\hline & $0.5 \%$ & $\begin{array}{c}+\mathbf{0 . 0 2 8} \\
N=15\end{array}$ & 0.267 & $\begin{array}{c}+\mathbf{0 . 0 0 4} \\
N=29\end{array}$ & 0.243 & $\begin{array}{c}+0.236 \\
N=41\end{array}$ & 0.011 & \multirow{8}{*}{$\begin{array}{c}+\mathbf{0 . 0 3 5} \\
N=49 \\
+0.056 \\
N=50 \\
+0.672 \\
N=51\end{array}$} & 0.072 & \multirow{8}{*}{$\begin{array}{c}+0.158 \\
N=60 \\
+0.275 \\
N=61\end{array}$} & 0.017 & \multirow[t]{8}{*}{$\begin{array}{c}-0.907 \\
N=64\end{array}$} & \multirow[t]{8}{*}{0.000} \\
\hline & $1 \%$ & $\begin{array}{c}+0.055 \\
N=15\end{array}$ & 0.197 & $\begin{array}{c}+\mathbf{0 . 0 0 5} \\
N=29\end{array}$ & 0.231 & $\begin{array}{c}+0.242 \\
N=41\end{array}$ & 0.010 & & 0.055 & & 0.004 & & \\
\hline & $2 \%$ & $\begin{array}{c}+0.291 \\
N=15\end{array}$ & 0.015 & $\begin{array}{c}+0.083 \\
N=29\end{array}$ & 0.074 & $\begin{array}{c}-0.818 \\
N=41\end{array}$ & 0.000 & & 0.000 & & & & \\
\hline & $4 \%$ & +0.438 & 0.000 & +0.504 & 0.000 & -0.046 & 0.077 & & & & & & \\
\hline & & $N=15$ & & $N=29$ & & $N=40$ & & & & & & & \\
\hline & $8 \%$ & +0.527 & 0.000 & +0.327 & 0.000 & & & & & & & & \\
\hline & & $N=15$ & & $N=32$ & & & & & & & & & \\
\hline & $16 \%$ & $\begin{array}{c}+0.783 \\
N=16\end{array}$ & 0.000 & & & & & & & & & & \\
\hline \multirow[t]{11}{*}{ Fagus } & $\begin{array}{l}\text { Lower } \\
\text { threshold }\end{array}$ & & & & & & & & & & & & \\
\hline & $0.5 \%$ & $\begin{array}{c}-0.950 \\
N=7\end{array}$ & 0.000 & $\begin{array}{c}-0.504 \\
N=20\end{array}$ & 0.000 & $\begin{array}{l}+0.351 \\
N=31\end{array}$ & 0.000 & \multirow{10}{*}{$\begin{array}{c}+0.154 \\
N=40 \\
+0.605 \\
N=40 \\
+0.202 \\
N=41\end{array}$} & 0.028 & \multirow{10}{*}{$\begin{array}{c}-\mathbf{0 . 0 2 1} \\
N=55 \\
-0.199 \\
N=51\end{array}$} & 0.079 & \multirow[t]{10}{*}{$\begin{array}{c}-0.219 \\
N=58\end{array}$} & \multirow[t]{10}{*}{0.009} \\
\hline & $1 \%$ & +0.696 & 0.000 & -0.112 & 0.081 & -0.439 & 0.000 & & 0.000 & & 0.014 & & \\
\hline & & $N=7$ & & $N=21$ & & $N=30$ & & & & & & & \\
\hline & $2 \%$ & +0.671 & 0.000 & -0.014 & 0.242 & +0.320 & 0.001 & & 0.017 & & & & \\
\hline & & $N=7$ & & $N=21$ & & $N=32$ & & & & & & & \\
\hline & $4 \%$ & +0.591 & 0.000 & -0.032 & 0.179 & -0.885 & 0.000 & & & & & & \\
\hline & & $N=7$ & & $N=21$ & & $N=32$ & & & & & & & \\
\hline & $8 \%$ & +0.594 & 0.000 & -0.088 & 0.096 & & & & & & & & \\
\hline & & $N=7$ & & $N=22$ & & & & & & & & & \\
\hline & $16 \%$ & $\begin{array}{l}+0.529 \\
N=7\end{array}$ & 0.000 & & & & & & & & & & \\
\hline \multirow[t]{9}{*}{ Picea } & $\begin{array}{l}\text { Lower } \\
\text { threshold }\end{array}$ & & & & & & & & & & & & \\
\hline & $0.5 \%$ & $-\mathbf{0 . 0 2 7}$ & 0.167 & $-\mathbf{0 . 0 3 0}$ & 0.094 & -0.057 & 0.057 & \multirow{8}{*}{$\begin{array}{c}-\mathbf{0 . 0 3 1} \\
N=51 \\
-\mathbf{0 . 0 0 8} \\
N=53 \\
-\mathbf{0 . 0 2 3} \\
N=58\end{array}$} & 0.073 & & 0.026 & -0.360 & 0.000 \\
\hline & & $N=24$ & & $N=40$ & & $N=48$ & & & & $N=58$ & & $N=67$ & \\
\hline & $1 \%$ & -0.020 & 0.173 & -0.053 & 0.068 & -0.055 & 0.055 & & 0.112 & -0.057 & 0.045 & & \\
\hline & & $N=26$ & & $N=42$ & & $N=50$ & & & & $N=60$ & & & \\
\hline & $2 \%$ & -0.129 & 0.056 & -0.187 & 0.019 & -0.131 & 0.025 & & 0.072 & & & & \\
\hline & & $N=26$ & & $N=43$ & & $N=55$ & & & & & & & \\
\hline & $4 \%$ & -0.141 & 0.050 & -0.227 & 0.012 & -0.124 & 0.027 & & & & & & \\
\hline & & $N=26$ & & $N=42$ & & $N=54$ & & & & & & & \\
\hline
\end{tabular}




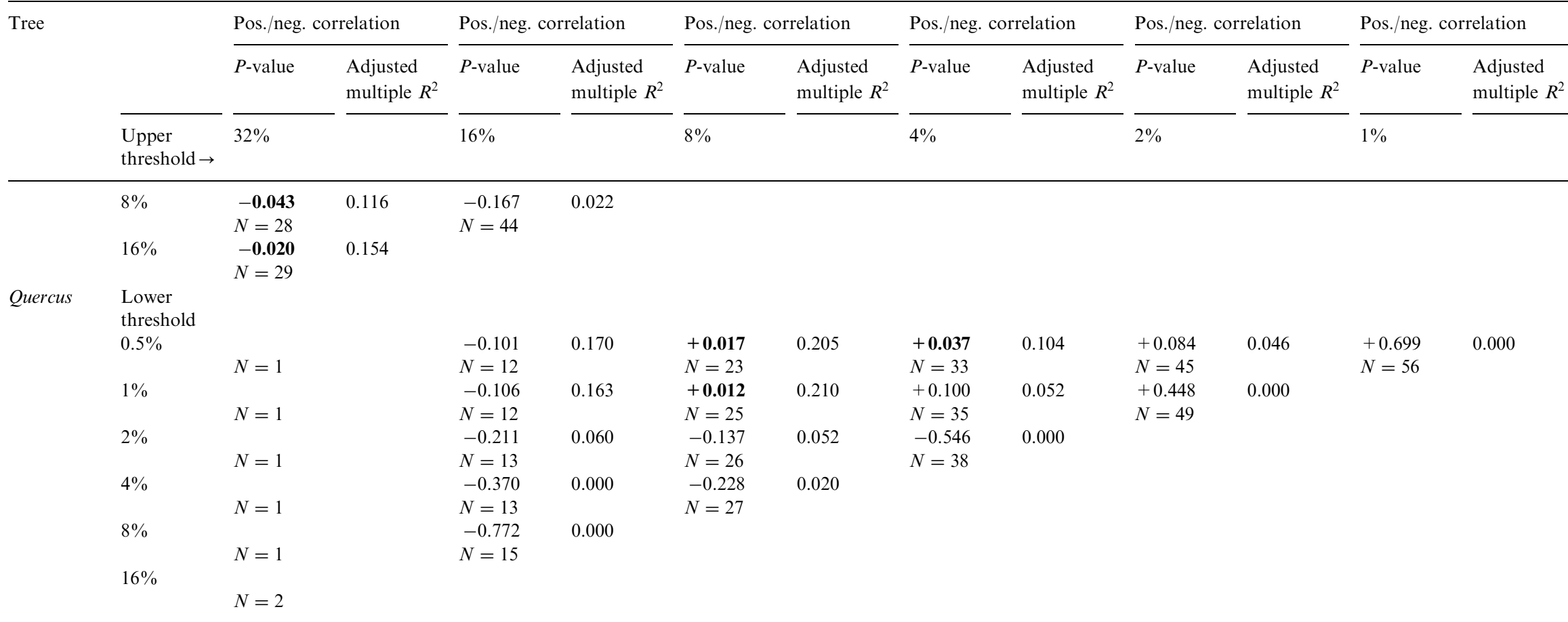

${ }^{\mathrm{a}}$ Sites used lie $>45.5^{\circ} \mathrm{N},>6^{\circ} \mathrm{E}$. Simple linear regression between pollen-percentage threshold age cal BP and pollen-percentage expansion duration (i.e., time lapse between age cal BP of one threshold (lower threshold; rows) and any higher threshold (upper threshold; columns)). $N=$ number of records, i.e., number of sites in which the expansion is recorded (i.e., both pollen-percentage thresholds crossed). Positive or negative correlation are indicated by + or - . Positive correlation indicates shorter expansion duration when expansion starts later, negative correlation indicates longer duration. Statistical significance $(P<0.05)$ is indicated by bold print. Adjusted multiple $R^{2}$ is proportion of variance explained. For $Q u e r c u s$ upper threshold $32 \%$ the number of records $N$ is insufficient for statistical treatment. 
south Switzerland (Ticino) ca. 9.5 ka cal BP. Results indicate that the inner-Alpine dry valleys have always been less suited for Abies than the peripheral, wetter parts of the Alps. The speed of Abies population expansion increased during the Holocene, possibly as a result of soil maturation favourable for this climax tree.

Fagus: Results indicate that Fagus migrated from north to south into the Alps, but no west-east direction is apparent. However, long periods of low pollen percentages preceding the first marked increase make it difficult to estimate the ages of establishment of the tree near sites. Results indicate that population expansion was earlier and faster in the north than in the south of the study area $\left(45.5-48.1^{\circ} \mathrm{N}, 6-14^{\circ} \mathrm{E}\right)$, and also faster at low elevation than at high elevation. Results indicate that the inner-Alpine dry valleys were as unsuited for Fagus in the past as they are today. The speed of Fagus expansion decreased during the Holocene, possibly as a result of human impact hampering the full development of forests in the later part of the Holocene.

Picea: Results indicate that Picea migrated from east to west along the Alps. The speed of Picea population expansion following arrival decreased during the Holocene, and increasingly smaller populations built up towards the west, for which at least three explanations are possible: either population expansion of Picea as a pioneer tree was slowed down through competition with the increasing numbers of tree species and with increasing soil maturation, or through westward migration the tree entered into areas with less suitable climate, or the general climate became less favourable for Picea during its migration.

Quercus. Results indicate that Quercus migrated very early from south to north, but more detail is not possible because of the high pollen production and effective long-distance pollen transport of Quercus smearing the signal. The speed of Quercus population expansion increased during its migration, which can be related to the climatic warming at the Younger Dryas-Holocene transition.

\section{Acknowledgements}

We thank data contributors Regula Gehrig, Isabelle Richoz, Willy Tinner, and Lucia Wick for their permission to use the pollen data that fall under their responsibilities. We thank Cesare Ravazzi for critical comments on the manuscript. We thank Herb Wright for linguistic corrections. We thank John Birks and an anonymous reviewer for comments. This study was carried out in the scope of EU project FOSSILVA (contract no. EVK2-CT-1999-00036), granted to the first author. This paper is a contribution to the Swiss National Science Foundation research project no. 3137620.93 .

\section{References}

Ammann, B., 1989. Late-Quaternary palynology at LobsigenseeRegional vegetation history and local lake development. Dissertationes Botanicae 137, 157pp.

Avigliano, R., di Anastasio, G., Improta, S., Peresani, M., Ravazzi, C., 2000. A new late glacial to early Holocene palaeobotanical and archaeological record in the Eastern Pre-Alps: the Palughetto basin (Cansiglio Plateau, Italy). Journal of Quaternary Science 15, 789-803.

Beaulieu, J.-L. de, 1977. Contribution pollenanalytique à l'histoire tardiglaciaire et Holocène de la végétation des Alpes méridionales françaises. Ph.D. Thesis, University Aix-Marseille (France). 358 $\mathrm{pp}+$ diagrams. No. D'enregistrement au C.N.R.S.: A.O. 12669.

Beaulieu, J.-L. de, Goeury, C., 1987. Zonation automatique appliquée à l'analyse pollinique: exemple de la Narse d'Ampoix (Puy de Dôme, France). Bulletin de l'Association française pour l'étude du Quaternaire 4, 49-61.

Beckmann, M., 2004. Pollenanalytische Untersuchung der Zeit der Jäger und Sammler und der ersten Bauern an zwei Lokalitäten des Zentralen Schweizer Mittellandes: Umwelt und erste Eingriffe des Menschen in die Vegetation vom Paläolithikum bis zum Jungneolithikum. PhD Thesis, Institut für Pflanzenwissenschaften, Bern, 2003 (Dissertationes Botanicae), in press.

Bennett, K.D., Tzedakis, P.C., Willis, K.J., 1991. Quaternary refugia of north European trees. Journal of Biogeography 18, 103-115.

Birks, H.J.B., 1986. Late-Quaternary biotic changes in terrestrial and lacustrine environments, with particular reference to north-west Europe. In: Berglund, B.E. (Ed.), Handbook of Holocene Palaeoecology and Palaeohydrology. Wiley, Chichester, pp. 3-65.

Birks, H.H., Birks, H.J.B., 2000. Future uses of pollen analysis must include plant macrofossils. Journal of Biogeography 27, 31-35.

Bortenschlager, S., 1970. Waldgrenz- und Klimaschwankungen im pollenanalytischen Bild des Gurgler Rotmooses. Mitteilungen der Ostalpin-Dinarischen Gesellschaft für Vegetationskunde 11, 19-26.

Bortenschlager, I., 1976. Beiträge zur Vegetationsgeschichte Tirols II: Kufstein - Kitzbühel - Pass Thurn. Berichte des naturwissenschaftlich-medizinischen Vereins in Innsbruck 63, 105-137.

Bortenschlager, S., 1984a. Beiträge zur Vegetationsgeschichte Tirols I. Inneres Öztal und unteres Inntal. Berichte des naturwissenschaftlich-medizinischen Vereins in Innsbruck 71, 19-56.

Bortenschlager, S., 1984b. Die Vegetationsentwicklung im Spätglazial: das Moor beim Lanser See III, ein Typprofil für die Ostalpen. Dissertationes Botanicae 72, 71-79.

Brewer, S., Cheddadi, R., de Beaulieu, J.-L., Data contributors 2002. The migration of deciduous Quercus throughout Europe since the last glacial period. Forest Ecology and Management 156(1-3), 27-48.

Brugiapaglia, E., 1996. Dynamique de la végétation tardiglaciaire et holocène dans les Alpes Italiennes nord-occidentales. Unpublished Ph.D. Thesis, Marseille, France.

Burga, C.A., Hussendörfer, E., 2001. Vegetation history of Abies alba Mill. (silver fir) in Switzerland - pollen-analytical and genetic surveys related to aspects of vegetation history of Picea abies (L.) H. Karsten (Norway spruce). Vegetation History and Archaeobotany 10, 151-159.

Burga, C.A., Perret, R., 1998. Vegetation und Klima der Schweiz seit dem jüngeren Eiszeitalter - Vegetation and climate history in Switzerland during the later Pleistocene and Holocene. Unter Mitarbeit von C. Vonarburg. Mit Beiträgen von U. Eicher, G.S. Lister, H.R. Bär, S. Jacomet, K.A. Hünermann, J.-M. Le Tensorer und M. Primas. Otto Verlag Thun, Thun, Switzerland 805pp.

Clerc, J., 1988. Recherches pollenanalytiques sur la paléoécologie Tardiglaciaire et Holocène du Bas-Dauphiné. Ph.D. Thesis, Univ. St. Jérôme, Marseille, France, 179pp. 
Davis, M.B., Sugita, S., 1997. Reinterpreting the fossil pollen record of Holocene tree migration. In: Huntley, B., Cramer, W., Morgan, A.V., Prentice, H.C., Allen, J.R.M. (Ed.), Past and Future Rapid Environmental Changes: The Spatial and Evolutionary Responses of Terrestrial Biota, NATO ASI Series I: Global Environmental Change, vol. 47, pp. 181-193.

de Valk, E.J., 1981. Late Holocene and present vegetation of the Kastelberg (Vosges, France). Ph.D. Thesis, University of Utrecht, The Netherlands, 294pp.

Fäh, J., 1986. Erste Ergebnisse der Untersuchung zur Entwicklung eines Hangmoores im Oberen Toggenburg (Kanton St. Gallen). Telma 16, 23-30.

Gaillard, M.-J., 1984. Evolution de la Végétation du Moyen-Pays Romand. Dissertationes Botanicae 77, 322.

Gaillard, M.-J., 1985. Late-Glacial and Holocene environments of some ancient lakes in the western Swiss Plateau. In: Lang, G. (Eds.), Swiss Lake and Mire Environments During the Last 15000 Years. Dissertationes Botanicae 87, 273-336.

Gardner, A.R., Willis, K.J., 1999. Prehistoric farming and the postglacial expansion of beech and hornbeam: a comment on Küster. The Holocene 9, 119-121.

Gehrig, R., 1997. Pollenanalytische Untersuchungen zur Vegetationsund Klimageschichte des Val Camonica (Norditalien). Dissertationes Botanicae 276, 152.

Gliemeroth, A.K., 1995. Paläoökologische Untersuchungen über die letzten 22'000 Jahre in Europa: Vegetation, Biomasse und Einwanderungsgeschichte der wichtigsten Waldbäume. Paläoklimaforschung 18, 1-252.

Gliemeroth, A.K., 1997. Holozäne Einwanderungsgeschichte der Baumgattungen Picea und Quercus unter paläoökologischen Aspecten nach Europa. Eiszeitalter und Gegenwart 47, 28-41.

Gobet, E., Tinner, W., Hubschmid, P., Jansen, I., Wehrli, M., Ammann, B., Wick, L., 2000. Influence of human impact and bedrock differences on the vegetational history of the Insubrian Southern Alps. Vegetation History and Archaeobotany 9, 175-187.

Gobet, E., Tinner, W., Hochuli, P.A., van Leeuwen, J.F.N., Ammann, B., 2003. Middle to Late Holocene vegetation history of the Upper Engadine (Swiss Alps); the role of man and fire. Vegetation History and Archaeobotany 12, 143-163.

Gulliksen, S., Birks, H.H., Possnert, G., Mangerud, J., 1998. A calendar estimate of the Younger Dryas-Holocene boundary at Kråkenes, western Norway. The Holocene 8, 249-259.

Hadorn, Ph., 1994. Saint-Blaise/Bains des Dames, 1. Palynologie d'un site néolithique et histoire de la végétation des derniers 16000 ans. Neuchâtel. Musée cantonal d'archéologie (Archéologie neuchâteloise) 18,121

Heeb, K., Welten, M., 1972. Moore und Vegetationsgeschichte der Schwarzenegg und des Molassevorlandes zwischen dem Aaretal unterhalb Thun und dem obern Emmental. Mitteilungen der Naturforschenden Gesellschaft in Bern (Neue Folge) 29, 2-54.

Heuberger, H., 1977. Gletscher- und klimageschichtliche Untersuchungen im Zemmgrund. Alpenvereins-Jb 1977, 39-50.

Huntley, B., Birks, H.J.B., 1983. An Atlas of Past and Present Pollen Maps for Europe, 0-13,000 Years Ago. Cambridge Press, New York.

Hüttemann, H., Bortenschlager, S., 1987. Beiträge zur Vegetationsgeschichte Tirols VI: Riesengebirge, Hohe Tatra-Zillertal, Kühtai. Berichte des naturwissenschaftlich-medizinischen Vereins in Innsbruck 74, 81-112.

Juvigné, E., Gewelt, M., 1987. La Narse d'Ampoix comme Téphrostratotype dans la Chaîne des Puys Méridionale (France). Bulletin de l'Association Française pour 1,Étude du Quaternaire 29, 37-49.

Krisai, R., Burgstaller, B., Ehmer-Künkele, U., Schiffer, R., Wurm, E., 1991 (appeared 1993). Die Moore des Ost-Lungaues - Heutige Vegetation, Entstehung, Waldgeschichte ihrer Umgebung. Sauteria 5: Institut für Botanik, Salzburg, pp. 1-240, 8 maps.
Küster, H., 1997. The role of farming in the postglacial expansion of beech and hornbeam in the oak woodlands of central Europe. The Holocene 7, 239-242.

Küster, H., 1999. Prehistoric farming and the postglacial expansion of beech and hornbeam: a reply to Gardner and Willis. The Holocene 9, 121-122.

Küttel, M., 1977. Pollenanalytische und geochronologische Untersuchungen zur Piottino-Schwankung (Jüngere Dryas). Boreas 6, 259-274.

Küttel, M., 1979. Pollenanalytische Untersuchungen zur Vegetationsgeschichte und zum Gletscherrückzug in den westlichen Schweizeralpen. Berichte der Schweizerischen Botanischen Gesellschaft 89, 9-62.

Küttel, M., 1989. Züge der jungpleistozänen Vegetations- und Landschaftsgeschichte der Zentralschweiz. Revue de Paléobiologie 8 (2), 525-614.

Landolt, E., 1983. Probleme der Höhenstufen in den Alpen. Botanica Helvetica 93, 255-268.

Lang, G., 1992. Some aspects of European late- and post-glacial flora history. Acta. Botanica. Fennica 144, 1-17.

Lotter, A., 1985. Amsoldingersee - Late-Glacial and Holocene environments of a lake at the southern edge of the Swiss Plateau. In: Lang, G. (Ed.), Swiss Lake and Mire Environments During the Last 15000 Years. Dissertationes Botanicae 87, 185-208.

Lotter, A., 1988. Paläoökologische und paläolimnologische Studie des Rotsees bei Luzern. Pollen-, grossrest-, diatomeen- und sedimentanalytische Untersuchungen. Dissertationes Botanicae 124, 1-187.

Lotter, A.F., Birks, H.J.B., 2003. Holocene sediments of Sägistalsee, a small lake at the present-day tree-line in the Swiss Alps. Journal of Paleolimnology 30, 253-260.

Lotter, A., Boucherle, M.M., 1984. A Late-Glacial and Post-Glacial history of Amsoldingersee and vicinity, Switzerland. Schweizerische Zeitschrift für Hydrologie 46, 192-209.

Lotter, A.F., Fischer, J., 1991. Vegetation und Flora im Gebiet des Aegelsees (Berner Oberland) im Wandel der Zeit: Vergangenheit, Gegenwart und Zukunft. Mitteilungen der Naturforschenden Gesellschaft Bern N.F. 47, 77-103.

Lotter, A.F., Ammann, B., Beer, J., Hajdas, I., Sturm, M., 1992. A step towards an absolute time-scale for the Late-Glacial: annually laminated sediments from Soppensee (Switzerland). In: Bard, E., Broecker, W. (Eds.), The Last Deglaciation: Absolute and Radiocarbon Chronologies. NATO ASI Series I 2, 45-68.

Lotter, A.F., Ammann, B., Hajdas, I., Sturm, M., van Leeuwen, J., 1996(?). Faulenseemoos revisited, new results from an old site. PACT 50-II5, 133-144.

Markgraf, V., 1969. Moorkundliche und vegetationsgeschichtliche Untersuchungen an einem Moorsee an der Waldgrenze im Wallis. Botanische Jahrbücher 89, 1-63.

Markgraf, V., 1972. Die Ausbreitungsgeschichte der Fichte (Picea abies H. Karst) in der Schweiz. Berichte der Deutschen Botanischen Gesellschaft 85 (1-4), 165-172.

Mitchell, E.A.D., van der Knaap, W.O., van Leeuwen, J.F.N., Buttler, A., Warner, B.G., Gobat, J.-M., 2001. The palaeoecological history of the Praz-Rodet bog (Swiss Jura) based on pollen, plant macrofossils and testate amoebae (Protozoa). The Holocene 11, $65-80$.

Nakagawa, T., 1998. Etudes palynologiques dans les Alpes françaises centrales et méridionales : histoire de la végétation tardiglaciaire et holocène. Ph.D. Thesis, Faculté des Sciences et Techniques de Saint-Jerôme, Université de Droit, d'Economie et des Sciences, Aix-Marseille III. 211 pp.

Nicol-Pichard, S., 1987. Analyse pollinique d'une séquence tardi et postglaciaire à Tourves (Var, France). Ecologia Mediterranea 13, 29-42.

Nicol-Pichard, S., Dubar, M., 1998. Reconstruction of Late-glacial and Holocene environments in south-east France based on the 
study of a 66-m long core from Biot, Alpes Maritimes. Vegetation History and Archaeobotany 7, 11-15.

Oeggl, K., 1988. Beiträge zur Vegetationsgeschichte Tirols VII: Das Hochmoor Schwemm bei Walchsee. Berichte des naturwissenschaftlich-medizinischen Vereins in Innsbruck 75, 37-60.

Ozenda, P., 1988. Die Vegetation der Alpen im europäischen Gebirgsraum. Fischer, Stuttgart, New York. 353 pp +1 map. [translation of: Ozenda, P., 1985. La végétation de la chaîne alpine dans l'espace montagnard européen. Masson, Paris.]

PanMap, 1998. http://www.pangaea.de/Software/PanMap/. Software developed at Alfred Wegener Institute for Polar and Marine Research Bremerhaven, Germany.

Pini, R., 2002. A high-resolution Late-Glacial-Holocene pollen diagram from Pian di Gembro (Central Alps, Northern Italy). Vegetation History and Archaeobotany 11, 251-262.

Ravazzi, C., 2002. Late Quaternary history of spruce in southern Europe. Review of Palaeobotany and Palynology 120, 131-171.

Reille, M., 1991. L'origine de la station de pin à crochets de la tourbière de Pinet (Aude) et de quelques stations isolées de cet arbre dans les Vosges et le Jura. Bulletin de la Société botanique de France, Lettres Botaniques 138 (2), 123-148.

Richoz, I., 1997. Etude paléoécologique du lac de Seedorf (Fribourg, Suisse). Histoire de la végétation et du milieu durant l'Holocène: le rôle de l'homme et du climat. Ph.D. Thesis, Faculté des Sciences, Université de Lausanne. 175 pp + Figures appended.

Rösch, M., 1983. Geschichte der Nussbaumer Seen (Kanton Thurgau) und ihrer Umgebung seit dem Ausgang der letzten Eiszeit aufgrund quartärbotanischer stratigraphischer und sedimentologischer Untersuchungen. Mitteilungen der Thurgauischen Naturforschenden Gesellschaft 45 pp. 1-110+17 figures.

Rösch, M., 1985. Nussbaumer Seen - spät- und postglaziale Veränderungen einer Seengruppe im östlichen schweizer Mittelland. In: Lang, G., (Ed.), 1985. Swiss Lake and Mire Environments During the Last 15000 Years. Dissertationes Botanicae 87, 337-379.

Schmidli, J., Schmutz, C., Frei, C., Wanner, H., Schär, C., 2002. Mesoscale precipitation variability in the region of the European Alps during the 20th century. International Journal of Climatology 22, 1049-1074.

Schneebeli, M., Küttel, M., Fäh, J., 1989. Die dreidimensionale Entwicklung eines Hanghochmoores im Toggenburg, Schweiz. Vierteljahrsschrift der Naturforschenden Gesellschaft in Zürich 134 (1), 1-32.

Schweizer, A., Kalis, A.J., van der Knaap, W.O., Urz, R., 2004. Advantages of combined macrofossil and pollen diagramsEvidence from a small fen in the Vosges Mountains, in preparation.

Seiwald, A., 1980. Beiträge zur Vegetationsgeschichte Tirols IV: Natzer Plateau - Villanderer Alm. Berichte des naturwissenschaftlich-medizinischen Vereins in Innsbruck 67, 31-72.

Stuiver, M., Reimer, P.J., Bard, E., Beck, J.W., Burr, G.S., Hughen, K.A., Kromer, B., McCormac, F.G., v.d. Plicht, J., Spurk, M., 1998a. Radiocarbon 40, 1041-1083.

Stuiver, M., Reimer, P.J., Braziunas, T.F., 1998b. Radiocarbon 40, 1127-1151 (revised dataset); Stuiver, M., Braziunas, T.F., 1993. The Holocene 3, 289-305 (original dataset).

Sugita, S., 1994. Pollen representation of vegetation in Quaternary sediments: theory and method in patchy vegetation. Journal of Ecology 82, 881-897.

SYSTAT 5.02, 1993. SYSTAT 5.02 for Windows, Coypright 1990-1993 by SYSTAT, Inc., Evanston, USA

Telford, R.J., Heegaard, E., Birks, H.J.B., 2004. All age-depth models are wrong: but how badly? Quaternary Science Reviews 23, 1-5.

Tinner, W., 1998. Quartärbotanische Untersuchungen zur Waldbrandökologie des Sottoceneri (Südschweiz). Ph.D Thesis, Geobotanical Institute, Bern.
Tinner, W., Conedera, M., 1995. Indagini paleobotaniche sulla storia della vegetazione e degli incendi forestali durante l'Olocene al Lago di Origlio (Ticino meridionale). Bollettino della Società Ticinese di Scienze Naturali (Lugano) 83 (1-2), 91-106.

Tinner, W., Lotter, A.F., 2001. Central European vegetation response to abrupt climate change at $8.2 \mathrm{ka}$. Geology 29, 551-554.

Tinner, W., Hubschmid, P., Wehrli, M., Ammann, B., Conedera, M., 1999. Long-term forest fire ecology and dynamics in southern Switzerland. Journal of Ecology 87, 273-289.

Valsecchi, V., 1999 (manuscript). Studio sulla storia della vegetazione dell'altopiano del Cansiglio (Prealpi Venete) con particolare riguardo alla riforestazione tardiglaciale. Università degli studi di Milano - Facoltà di Scienze Matematiche, Fisiche e Naturali Corso di Laurea in Scienze Naturali. Tesi di Laurea - Master's Thesis No. 486442, 87pp.

van der Knaap, W.O., Ammann, B., 1997. Depth-age relationships of 25 well-dated Swiss Holocene pollen sequences archived in the Alpine Palynological Data-Base. Revue de Paléobiologie, Genève 16 (2), 433-480.

van der Knaap, W.O., van Leeuwen, J.F.N., 1997. Late Glacial and early Holocene vegetation succession, altitudinal vegetation zonation, and climatic change in the Serra da Estrela, Portugal. Review of Palaeobotany and Palynology 97, 239-285.

van der Knaap, W.O., van Leeuwen, J.F.N., 2001. Vegetationsgeschichte und menschlicher Einfluss in der Umgebung des Bibersees zwischen 2600 und 50 v. Chr. In: Gnepf Horisberger, U., Hämmerle, S. (Eds.), Cham-Oberwil, Hof (Kanton Zug)Befunde und Funde aus der Glockenbecherkultur und der Bronzezeit. Antiqua 33. Schweizerische Gesellschaft für Ur- und Frühgeschichte, Basel. pp. 181, 194-199.

van der Knaap, W.O., van Leeuwen, J.F.N., Fankhauser, A., Ammann, B., 2000. Palynostratigraphy of the last few centuries in Switzerland based on 23 lake and mire deposits: chronostratigraphic pollen markers, regional patterns, and local histories. Review of Palaeobotany and Palynology 108, 85-142.

van der Knaap, W.O., van Leeuwen, J.F.N., Ammann, B., 2004. The first rise and fall of Fagus sylvatica and interaction with Abies alba at Faulenseemoos (Swiss Plateau) 6900-6000 cal yr BP: Ellenberg's ecological indicator values for plants applied to a pollen diagram. Acta Palaeobotanica, in press.

Vorren, K.-D., Mørkved, B., Bortenschlager, S., 1993. Human impact on the Holocene forest line in the Central Alps. Vegetation History and Archaeobotany 2, 145-156.

Wahlmüller, N., 1985. Beiträge zur Vegetationsgeschichte Tirols V: Nordtiroler Kalkalpen. Berichte des naturwissenschaftlich-medizinischen Vereins in Innsbruck 72, 101-144.

Wahlmüller, N., 1988. Pollenanalytische Untersuchungen am Götschenberg bei Bischofshofen/Salzburg. Berichte des naturwissenschaftlich-medizinischen Vereins in Innsbruck 2 (Suppl.), $13-26$.

Wahlmüller, N., 1990. Spät- und postglaziale Vegetationsgeschichte des Tschögglberges (Südtirol). Berichte des naturwissenschaftlichmedizinischen Vereins in Innsbruck 77, 7-16.

Wahlmüller, N., 1992. Beitrag der Pollenanalyse zur Besiedlungsgeschichte des Haidberges bei Bischofshofen/Salzburg (mit 5 Pollendiagrammen: Plan 9-13). In: Lippert, A. (Ed.), Der Götschenberg bei Bishofshofen-Eine ur- und frühgeschichtliche Höhensiedlung im Salzachpongau. Mit Beiträgen von P. Gstrein, H. Fuchs, J.-M. Schramm, B. Ottaway, M. Wilhelmy, N. Wahlmüller, H Moesta und J. Peters. Verlag der Österreichischen Akademie der Wissenschaften, Wien.

Watson, C.S., 1996. The vegetational history of the northern Apennines, Italy: information from three new sequences and a review of Regional vegetational change. Journal of Biogeography 23, 805-841. 
Watts, W.A., 1973. Rates of change and stability in vegetation in the perspective of long periods of time. In: Birks, H.J.B., West, R.G. (Eds.), Quaternary Plant Ecology. Blackwell, Oxford, pp. 195-206.

Wegmüller, S., 1977. Pollenanalytische Untersuchungen zur spät- und postglazialen Vegetationsgeschichte der französischen Alpen (Dauphiné). Verlag Paul Haupt, Bern. 1985pp +5 diagrams.

Wegmüller, S., Lotter, A.F., 1990. Palynostratigraphische Untersuchungen zur spät- und postglazialen Vegetationsgeschichte der nordwestlichen Kalkvoralpen. Botanica Helvetica 100, 37-73.

Wegmüller, S., Welten, M., 1973. Spätglaziale Bimstufflagen des Laacher Vulkanismus im Gebiet der westlichen Schweiz und der Dauphin, (F.). Eclogae Geologicae Helveticae 60 (3), $533-541$.

Weirich, J., Bortenschlager, S., 1980. Beiträge zur Vegetationsgeschichte Tirols III: Stubaier Alpen-Zillertaler Alpen. Berichte des naturwissenschaftlich-medizinischen Vereins in Innsbruck 67, 7-30.
Welten, M., 1977. Résultats palynologiques sur le développement de la végétation et sa dégradation par l'homme à l'étage inférieur du Valais Central (Suisse). Bulletin de l'Association Française pour l'Étude du Quaternaire 47 (Suppl.), 303-307.

Welten, M., 1982a. Vegetationsgeschichtliche Untersuchungen in den westlichen Schweizer Alpen: Bern-Wallis. Denkschriften der Schweizerischen Naturforschenden Gesellschaft, vol. 95, DSNG 95, Textheft $104 \mathrm{pp}+$ Diagrammheft 37 diagrams.

Welten, M., 1982b. Pollenanalytische Untersuchungen zur Vegetationsgeschichte des Schweizerischen Nationalparks. Ergebnisse der wissenschaftlichen Untersuchungen im Schweizerischen Nationalpark XVI/80, 1-43 + 8 Figs.

Wick, L., 2004. Lago di Annone (Italy), in preparation.

Zbinden, H., Andrée, M., Oeschger, H., Ammann, B., Lotter, A., Bonani, G., Wölfli, W., 1989. Atmospheric radiocarbon at the end of the last glacial: an estimate based on AMS radiocarbon dates on terrestrial macrofossils from lake sediments. Radiocarbon 31, 795-804. 